NBER WORKING PAPER SERIES

\author{
DO FINANCLAL INCENTIVES ENCOURAGE \\ WELFARE RECIPIENTS TO WORK? \\ EVIDENCE FROM A RANDOMIZED \\ EVALUATION OF THE \\ SELF-SUFFICIENCY PROJECT
}

David Card

Philip K. Robins

NBER Working Paper 5701

\author{
NATIONAL BUREAU OF ECONOMIC RESEARCH \\ 1050 Massachusetts Avenue \\ Cambridge, MA 02138 \\ August 1996
}

We are grateful to Gordon Berlin, Judith Gueron, Barbara Goldman, Scott Murray, Richard Veevers, and Ann Brown for their continuing support, suggestions, and encouragement. Many individuals contributed importantly to this research, including Linda Duffy, Greg Hoerz, Winston Lin, David Long, Susanna Lui-Gurr, Tod Mijanovich, Lynn Miyazaki, Gail Quets, and Irene Robling. We have also benefitted from comments of Charles Beach and Rebecca Blank, and seminar participants at the NBER, the Institute for Research on Poverty, and Princeton University. The Self-Sufficiency Project is funded under a contributions agreement with Human Resources Development Canada. The findings and conclusions stated in this paper do not necessarily represent the official positions or policies of HRDC. This paper is part of NBER's research program in Labor Studies. Any opinions expressed are those of the authors and not those of the National Bureau of Economic Research.

(C) 1996 by David Card and Philip K. Robins. All rights reserved. Short sections of text, not to exceed two paragraphs, may be quoted without explicit permission provided that full credit, including $(\mathcal{O}$ notice, is given to the source. 
NBER Working Paper 5701

August 1996

\title{
DO FINANCIAL INCENTIVES ENCOURAGE \\ WELFARE RECIPIENTS TO WORK? \\ EVIDENCE FROM A RANDOMIZED \\ EVALUATION OF THE \\ SELF-SUFFICIENCY PROJECT
}

\begin{abstract}
This paper reports on a randomized evaluation of an earnings subsidy offered to long-term welfare recipients in Canada. The program -- known as the Self-Sufficiency Project (SSP) -provides a supplement equal to one-half of the difference between a target earnings level and a participant's actual earnings. The SSP supplement is similar to a negative income tax with two important differences: (1) eligibility is limited to long-term welfare recipients who find a full-time job; and (2) the payment depends on individual earnings rather than family income. Our evaluation is based on a classical randomized design: one half of a group of single parents who had been on welfare for over a year were eligible to receive the SSP supplement, while the other half were assigned to a control group. Results for an early cohort of SSP participants and controls suggest that the financial incentives of the Self-Sufficiency Program increase labor market attachment and reduce welfare participation.
\end{abstract}

David Card

Department of Economics

Princeton University

Princeton, NJ 08544

and NBER

decard@marlowe.princeton.edu
Philip K. Robins

Department of Economics

University of Miami

Coral Gables, FL 33124 
In Canada, as in the United States, welfare expenditures and caseloads have expanded steadily over the past three decades. Between 1981 and 1991, for example, federal and provincial expenditures associated with the Canada Assistance Plan almost tripled, with increases in individual provinces ranging from 200 to almost 500 percent (Courchene, 1994). Faced with rising welfare costs and budget deficits, Canadian policymakers have begun searching for measures to increase welfare recipients' self-sufficiency and reduce their dependence on government transfers.

Most welfare recipients in Canada do not work. For example, in British Columbia and New Brunswick, only about 20 percent of single parents who receive public assistance report any earnings in a given month. ${ }^{1}$ This circumstance, of course, is not unique to Canada -- the proportion of welfare recipients who work in the United States is also small. The low rates of labor market attachment on both sides of the border reflect a similar dilemma for many welfare recipients. On the one hand, available jobs tend to pay low wages; on the other hand, by reducing benefits by up to a dollar for every dollar of earnings, the welfare system imposes a very high "tax rate" on recipients' work effort.

This paper presents early findings from an experimental evaluation of a new program designed to encourage work and self-sufficiency among the welfare population in Canada. The program -- known as the Self-Sufficiency Project or SSP -- attempts to balance the dual challenges of low wages and high marginal tax rates by offering an earnings subsidy to welfare recipients who find a full-time job and leave welfare. Specifically, participants in the SSP program receive one-half of the difference between their actual eamings and an earnings "target" set considerably above the level of welfare benefits available to most families. The SSP evaluation is based on a randomized design: one-half of a group of long-term welfare recipients in two provinces (British Columbia and New Brunswick) were eligible for the supplement (the program group); the other half were not (the control group). As in other recent evaluations of

\footnotetext{
${ }^{1}$ This figure is based on household survey data from the Self-Sufficiency Project. Official welfare records exhibit somewhat lower employment rates.
} 
U.S. welfare programs (see, for example, Friedlander and Burtless, 1995), this randomized design makes it possible to draw credible inferences about the impact of SSP from simple comparisons between the outcomes of those who were offered the supplement and those who were not.

The full SSP evaluation entails a five-year follow-up of some 6,000 families. The findings in this paper are based on the first 18-24 months of follow-up data for about 2,000 families in an initial cohort of SSP enrollees. ${ }^{2}$ Already, however, systematic and highly significant differences in labor market attachment and welfare participation rates between the program and control groups suggest that the financial incentives of SSP affect a sizeable proportion of singleparent welfare recipients.

As background information for the SSP demonstration, Section I describes the nature of the work incentives facing Canadian welfare recipients. Section II describes the design of SSP and discusses the incentive effects of the program using a standard labor supply framework. Section III describes the characteristics of the research sample analyzed in this paper. Section IV presents estimates of the impact of the SSP program on labor market outcomes and welfare receipt. Section $\mathrm{V}$ presents some preliminary findings on the extent to which responses to the SSP program vary with the relative generosity of the supplement. Section VI analyzes the wages of jobs taken by SSP participants, and Section VII discusses possible response biases that affect the size of the impacts reported in the main body of the paper. Finally, Section VIII summarizes the paper's findings and outlines the evaluation's future research.

\section{Work Incentives in the Canadian Welfare System}

There is no single national welfare program in Canada. Instead, the Canada Assistance Plan specifies a cost-sharing arrangement between the federal and provincial governments and

\footnotetext{
${ }^{2}$ These individuals were enrolled in the SSP demonstration between November 1992 to December 1993.
} 
each province administers its own welfare, or Income Assistance (IA), program. Nevertheless, the provincial IA systems share many key features, most notably that IA applicants are subject to a "needs test" and that IA payments are offset by income from employment or other sources. IA benefits are linked to family size: in 1992, a single parent with one child was entitled to a maximum of $\$ 9,841$ per year in New Brunswick (one of the less generous provinces) and $\$ 12,478$ per year in British Columbia (one of the more generous provinces). ${ }^{3}$

IA recipients are discouraged from working by benefit rules that reduce IA payments dollar-for-dollar with any eamings (or other income) above a modest "disregard" amount (e.g. $\$ 200$ per month for single-parent families in New Brunswick). Canadian welfare recipients who work also stand to lose certain in-kind benefits, including subsidized housing, free dental services, and prescription drugs. (Unlike the United States, there is no food stamp program in Canada). Finally, welfare recipients' eamings are subject to payroll and income taxes. The latter are especially important because, except for the first few hundred dollars of wages, higher earnings reduce the income tax credit paid to low-income families, leading to a net positive income tax liability. The combination of a 100 percent implicit tax rate in the welfare system and a significant marginal tax rate in the income tax system creates a strong disincentive to work for many IA recipients.

\section{The Self-Sufficiency Project}

The work disincentives built into the Canadian welfare system pose a critical question for policymakers. If incentives could be modified to "make work pay," would a larger fraction of IA recipients take jobs and leave welfare? Over the past 25 years, a variety of programs have been proposed and implemented (some experimentally) to answer this question, including a

\footnotetext{
${ }^{3}$ See National Council of Welfare, 1992, and Blank and Hanratty, 1992, for a detailed comparison of the U.S. and Canadian welfare systems. All monetary figures presented in this paper are in Canadian dollars.
} 
negative income tax (NIT), enhanced or flexible earnings disregards (see Greenberg, Michalopoulos, Robins, and Wood, 1995), income tax credits (e.g. the Earned Income Tax Credit in the United States), and direct job training or placement services. The available evidence suggests that few of these programs have a large effect on work activity. Research on the experimental NIT programs run in the United States and Canada in the 1970s concluded that they increased work incentives for some families and reduced them for others, with a net negative effect on work for eligible families. Research on enhanced earnings disregard programs points to a similarly mixed conclusion. Although a higher earnings disregard increases work incentives for non-working welfare recipients, it may lower work incentives for those who are working, and it may encourage some non-recipients to enter welfare (Moffitt, 1992). Tax credit programs lead to the same combination of higher work incentives for some (at the lowest levels of earnings) and reduced work incentives for others (whose earnings fall in the "phase-out" range). ${ }^{5}$ Finally, evaluations of many different types of employment, education, and training services programs suggest that most have only a modest capacity to increase employment and earnings, although some specific programs have been more successful. ${ }^{6}$

In this context, the SSP supplement was conceived as an alternative approach to encouraging work among welfare recipients, with explicit provisions to minimize the labor supply disincentives of a conventional negative income tax. ${ }^{7}$ The three key ingredients of the SSP program are: (1) a substantial financial incentive for work relative to non-work, (2) a relatively low marginal tax rate on the earnings of those who work, and (3) a "full-time" work requirement

\footnotetext{
${ }^{4}$ NIT experiments were conducted in both Canada and the United States. For a discussion of the Canadian NIT experiment see Hum and Simpson, 1991. For a discussion of the U.S. NIT experiments see Moffitt and Kehrer, 1981; Robins, 1985; and Munnell, 1986.

${ }^{5}$ See Kesselman and Riddell, 1991; Hoffman and Seidman, 1990; and Scholz, 1993; for analyses of various tax credit programs.

${ }^{6}$ See Gueron, 1991; Gueron and Pauly, 1991; Greenberg and Wiseman, 1992; and Riccio, Friedlander, and Freedman, 1994.

${ }^{7}$ The iden of an earnings supplement was conceived by an advisory committee of the Innovations Branch of Human Resources and Development Canada. For details on how the program model was chosen and implemented, see SRDC, 1993 and Greenberg, Long, Meyer, Michalopoulos, and Robins, 1995.
} 
(30 hours per week) that prevents most people from reducing their work hours in response to the program.

\section{A. The Earnings Supplement}

Assuming that the 30-hour work requirement is met, the SSP eamings supplement is equal to half the difference between a participant's gross labor earnings and a target or "break-even" eamings level. ${ }^{8}$ Unearned income (such as child support or rental receipts) or eamings of other family members do not affect the supplement payment. The supplement is also independent of family size. During the first year of the SSP demonstration, the target earnings level was set at $\$ 37,000$ in British Columbia and $\$ 30,000$ in New Brunswick (Canadian dollars). These levels were designed to provide a substantial work incentive for most families. For example, a British Columbia participant who worked 30 hours per week (1,500 hours per year) at $\$ 7$ per hour (1 dollar above the minimum wage) would earn $\$ 10,500$ per year and collect a $\$ 13,250$ SSP supplement.

Figures 1 to 3 show simplified relationships between hours of work and total income under IA and SSP for a single parent with one child who earns the minimum wage in British Columbia and New Brunswick. ${ }^{9}$ The two figures for British Columbia reflect the two different earnings disregards in that province's IA program: the basic eamings disregard ( $\$ 200$ per month) and an enhanced disregard (\$200 plus 25 percent of eamings) available during the first 12 months of employment. As the figures make clear, SSP has two essential differences from the conventional welfare program. First, SSP offers substantially higher total income than IA for a "full-time" job (30 or more hours per week). Second, unlike IA, which has a 100 percent tax rate on

\footnotetext{
${ }^{8}$ Formally, the supplement is given by $S=.5\left(E^{*}-E\right)$, where $S$ is the supplement, $E^{*}$ is the target eamings level, and $\mathrm{E}$ is actual earnings. This is a conventional NIT formula, except that benefits are available only for fulltime workers and depend on individual earnings rather than family income.

${ }^{9}$ These figures do not take into account the interactions of SSP or IA with other tax and transfer programs. Since SSP benefits are subject to provincial and federal income taxes, and IA benefits are not, the relative generosity of SSP is exaggerated in the figures. The relative generosity of SSP for larger families is over-stated in Figure 1-3, since IA benefits rise with family size while SSP benefits do not.
} 
additional earnings, SSP benefits are reduced by only $\$ .50$ for each $\$ 1.00$ of earnings. Thus, SSP offers a financial incentive for higher work effort and also rewards individuals who find a higher-wage job. While Figures 1 to 3 ignore child care costs and the complex interaction between SSP and the provincial and federal income tax systems, the basic character of the SSP/IA comparison is unchanged when these issues are taken into account. As described more fully in Section V, most single parents' net incomes (accounting for taxes, child care costs, and so forth) are $\$ 3,000$ to $\$ 5,000$ per year higher under SSP than if they had worked the same amount and remained on IA.

\section{B. Eligibility Requirements}

Eligibility for the SSP demonstration was limited to single parents who had been on IA for at least 12 of the previous 13 months. ${ }^{10}$ People who were assigned to the program group were given up to 12 months from the date of notification of eligibility to obtain a full-time job and initiate a first supplement payment. Those who began receiving SSP payments within this time frame then became eligible for SSP supplements over the next three years (that is, for up to 36 months after the date of their first supplement payment). Those who did not initiate an SSP payment within the initial 12-month period lost any further eligibility. Supplement initiators were required to discontinue IA receipt, although they could retum to IA (and give up the supplement payments) at any time during their period of eligibility.

The SSP earnings supplement is paid monthly and is limited to individuals who work a minimum of 30 hours per week during the month and who earn at least the minimum wage. Supplement recipients are required to mail in pay stubs verifying their hours of work and earnings for the month. Individuals who do not meet the minimum 30-hour work requirement

\footnotetext{
${ }^{10}$ This limit on eligibility was intended both to reduce the incentive for people to apply for IA simply to gain eligibility for SSP (so-called entry effects), and also to target program resources to recipients with the greatest difficulties in getting off welfare. A separate experiment is being conducted in British Columbia to measure whether new applicants to IA extend their welfare spells to become eligible for SSP.
} 
for any given month may receive a pro-rated portion of their supplement for the period. However, pro-rating over a "partial month" is permitted only twice during each 12 -month period - after that the supplement is discontinued until the full-time hours threshold is met again.

\section{Other Features of SSP}

The mandate of the SSP demonstration to test a voluntary earnings supplement poses a potential problem for implementation. On the one hand, for the demonstration to replicate an on-going program, it is important that individuals understand the details of the program and the potential benefits of finding a full-time job. On the other hand, it is vital that the SSP evaluation not be compromised by "Hawthorne effects" arising from special treatment of the participants, or by the availability of extra services to the program group. Thus, the SSP "treatment" combined an outreach program designed to inform the program group about the benefits and operation of the supplement with a modest package of information and referrals to existing community services. Once informed about their eligibility for the SSP supplement, potential participants were asked to attend an information workshop at an SSP office, where program staff explained the supplement offer and provided information on the child care, housing, transportation, and job-counselling services available to all IA recipients. "

In the 12-month period of potential eligibility for an initial supplement payment, SSP staff regularly contacted the program group members to answer questions about the supplement and to invite them to a money management workshop. After the expiration of their one-year eligibility window, program group members who chose not to initiate a supplement were no longer contacted by SSP staff. Those who initiated a supplement continued to receive supplement payments if they met the eligibility requirements. They were invited to attend further money management workshops, but post-supplement contact was limited and mainly client-driven.

\footnotetext{
${ }^{11}$ Ninety-six percent of people assigned to the SSP program group attended the initial information session.
} 


\section{Expected Impacts}

The expected impacts of the SSP program depend on incentives that vary from person to person and over time, depending on what individuals would do in the absence of the program. For analytical purposes, it is useful to distinguish between four "counterfactual" groups, based on whether an individual would work more or less than 30 hours per week in the absence of the SSP supplement offer, and whether an individual would have continued to receive IA payments in the absence of SSP. ${ }^{12}$ By design, SSP participants who work full-time receive a higher income than they would under IA for a similar or lesser amount of work. Thus, standard economic theory suggests that the SSP supplement will induce some people who otherwise would have remained on IA and worked less than 30 hours per week to move from welfare to full-time employment. A similar prediction holds for people who otherwise would be off IA and either working part time or not at all. These predicted positive effects for non-workers and part-time workers will be larger, the bigger the net income for a full-time job under SSP relative to net income in the absence of the supplement, and the more that individuals value extra income versus non-working time (i.e., the larger the compensated wage elasticity of labor supply).

Individuals who would have worked full time in the absence of a supplement offer receive a windfall from the SSP program. These people can receive a supplement without changing their work hours, and some of them may be able to cut their hours and still remain eligible. Consider first individuals in the "windfall group" who otherwise would have been off IA. The supplement offer provides them with higher net income, and also lowers their net wage, since once on SSP each additional dollar of eamings reduces their supplement payment by 50 cents. For these individuals, standard economic theory predicts that the supplement will reduce hours and earnings. ${ }^{13}$ By comparison, for individuals who would have worked full time but remained on IA, the effect of the SSP supplement is ambiguous because the supplement raises their net income

\footnotetext{
${ }^{12}$ All four of these "counterfactual" groups are present in the control group in later months of the demonstration.

${ }^{13}$ This is the standard response to a negative income tax.
} 
(reducing work incentives) but raises their net wage (possibly increasing work incentives).

Overall, then, the expected impacts of the SSP program depend on three factors: the fractions of individuals on and off IA working full time or less than full time in the absence of the program; the relative generosity of the program; and the willingness of individuals to substitute non-working time for income. The smaller the fraction of people who would be expected to work full time in the absence of the program, the more likely the program is to generate increases in work effort (higher hours, earnings, and full-time employment rates). The larger the fraction of people for whom SSP is a windfall, the smaller the predicted effects of the program. This reasoning suggests that the actual effect of the SSP program may vary over the course of the demonstration, with potentially smaller effects later in the demonstration, when a larger fraction of participants might have been expected to be working full time anyway.

Another consideration that arises in predicting the impact of the SSP program is stigma. Existing research suggests that many welfare participants have a strong distaste for "being on welfare": They resent the reporting requirements imposed by the system or feel ostracized by friends and social contacts (Moffitt, 1983b). Since the SSP supplement does not depend on living arrangements or on other family members' incomes, and the program requires no contact with case workers, some people may prefer to leave welfare and participate in SSP even if the financial gain is relatively modest. To the extent that individuals attach greater stigma to continuing IA receipt than to SSP participation, one would expect an additional positive effect of SSP on full-time employment, hours, and earnings.

\section{The SSP Research Sample}

The SSP research sample was randomly selected from administrative rosters of IA recipients in the lower mainland of British Columbia and in southern New Brunswick who were: (1) single parents, (2) over 18 years of age, and (3) had received IA payments for at least 12 of the past 13 months. No other restrictions (for example, on health status) were imposed on 
eligibility. Intake for the first cohort of the research sample began in November 1992 and continued through December 1993. ${ }^{14}$ Recruitment and intake for a second cohort began in January 1994 and continued until March 1995.

Sample members were contacted at home and informed that they had been selected to participate in a research project involving the possibility of a wage supplement. They were then asked to sign an informed consent waiver granting access to various administrative records (including federal tax records) and to complete a baseline interview. Roughly 90 percent of selected individuals agreed to participate, yielding a first cohort research sample of 2,122 (701 from New Brunswick and 1,421 from British Columbia). After signing the consent waiver and completing the baseline interview, sample members were randomly assigned to either the control group (1,056 individuals) or the program group (1,066 individuals).

Data on the research sample are currently available from the baseline survey, IA administrative records, SSP Program Management Information System records, and a survey conducted at approximately 18 months after the date of random assignment. (Additional surveys are scheduled for 36 and 54 months after the date of random assignment.) The baseline survey collected retrospective labor market information from the time of enrollment back until approximately one year before enrollment. The 18 -month survey collected similar retrospective data from the time of the survey back to the date of enrollment.

Unfortunately, not all individuals in the first cohort of the research sample could be located or would agree to participate in the 18 -month survey. The overall response rate was 90 percent, and was slightly higher in New Brunswick (92 percent) than in British Columbia (89 percent). While high by conventional standards, the response rate was significantly lower for the SSP program group ( 88 percent) than for the control group ( 92 percent). This difference introduces a potential bias into comparison of outcomes between the program group members and control

\footnotetext{
${ }^{14}$ SSP intake was staggered over a two-year period to ease program management and to allow a relatively small staff to provide information sessions for sample members who were offered the wage supplement.
} 
group members who responded to the 18-month survey. Nevertheless, most of the analysis in this paper is based on the subset of program and control group members who responded to the 18-month survey. A formal analysis of the potential biases due to differential response rates is presented in Section VII below. For simplicity, we refer to the subsample of individuals who responded to the 18-month survey as the "18-month sample". It consists of 1,910 individuals: 942 program group members and 968 control group members, with 1,264 individuals from British Columbia and 646 from New Brunswick.

\section{A. Overview of the Provincial Labor Market Settings}

Before describing the SSP research samples in more detail, it is useful to describe the labor market context for the SSP evaluation. Table 1 summarizes some relevant information about the British Columbia and New Brunswick economies, as well as the IA and SSP program parameters in the two provinces. British Columbia is the third largest province in Canada (population 2.9 million) while New Brunswick is much smaller ( 0.6 million); together, they comprise about 15 percent of Canada's total population. In both provinces, labor market conditions improved slightly over the 1992 to 1994 period, although unemployment rates remained at relatively high levels. British Columbia had a higher employment-to-population ratio and a lower unemployment rate than New Brunswick, but a higher proportion of families in poverty. During the sample period the minimum wage was $\$ 1.00$ higher in British Columbia than in New Brunswick $(\$ 6.00$ versus $\$ 5.00$ per hour). Average monthly earnings of full-time female workers were similarly about 25 percent higher in British Columbia.

Average IA benefit rates are about 30 percent more generous in British Columbia, averaging $\$ 1,079$ per month, versus $\$ 733$ in New Brunswick. The more generous welfare system in British Columbia is one reason why the SSP break-even level was set higher there than in New Brunswick. Overall, however, the SSP program is potentially a bit more generous in New Brunswick: For an individual working 30 hours per week at the minimum wage in both 
provinces, gross eamings and SSP supplements are more than twice the average IA benefits in New Brunswick, whereas the relative difference is somewhat smaller in British Columbia.

\section{B. The SSP Samples: Descriptive Statistics}

Table 2 contains information on the characteristics of the 1,910 individuals in the 18-month sample (that is, individuals in the first cohort of the SSP sample who responded to the 18-month survey). The data are taken mainly from the baseline survey, although some information from IA administrative records is also presented. Column 1 of the table shows the average characteristics of the full sample, while columns 2 and 3 show data separately by province. Columns 4 and 5 show mean characteristics for sample members in the program group (those eligible for SSP subsidies) and for those in the control group (those not eligible for SSP subsidies). Finally, column 6 presents the t-statistics associated with a test to determine whether the mean characteristics of the program group and control group are identical. ${ }^{15}$

The personal and family background characteristics in Table 2 suggest that the SSP target group are mainly female, have relatively low levels of education, and grew up in families with poorly-educated parents. A sizeable percentage ( 35 to 45 percent) were raised by a single parent or in some other non-traditional family arrangement, and many report that their own parents received some form of welfare. On average, sample members have 1.5 children, and virtually all need some child care services.

The IA and work histories of the research sample are also informative. Sample members received IA payments in 30 of the last 36 months, on average, and about 60 percent had been on IA continuously for over two years. The average IA benefit amount received in the month before random assignment was $\$ 655$ in New Brunswick and $\$ 1,004$ in British Columbia. These amounts are about 10 percent lower than the average statutory benefit rates for single parents

\footnotetext{
${ }^{15}$ Assuming random assignment and ignoring non-response to the 18-month survey, the means of the program group and the control group should be significantly different only by chance.
} 
with the average number of children in the respective provinces (see Table 1), reflecting benefit reductions for earnings and other factors.

Almost all of the sample members report that they have worked for pay at some time in the past. Indeed, the average number of years of paid employment is fairly high (6 to 8 years, depending on the province). Nevertheless, only about 20 percent worked in the month before random assignment, and the mean number of months worked in the 10 months prior to the baseline is 2. Average earnings (among those who worked) are about $\$ 500$ per month in New Brunswick and $\$ 600$ in British Columbia. The gap is consistent with other data showing roughly 20 percent higher wages in British Columbia than in New Brunswick.

On the basis of the information in Table 2, two primary conclusions can be drawn about the SSP target population. First, the target group -- single parents with a lengthy history of IA receipt -- are mainly poorly educated women from disadvantaged family backgrounds. Normally, such individuals would be expected to have low wages and intermittent employment histories. Second, although most of the SSP population has held a job sometime in the past, and many have long work histories, their recent labor market attachment is relatively weak. Thus, the SSP population could be characterized as having relatively disadvantaged "permanent characteristics" (such as education and family background) and relatively poor "transitory outcomes" (such as low levels of work in the past year). This combination suggests that, in the absence of the SSP program, we might expect to see some modest improvement in labor market outcomes for many of the sample members over the next few years, but that members of the SSP target population would be likely to experience low wages and intermittent employment rates. 


\section{Basic Impacts During the First 18 Months}

\section{A. Methodology}

Although a full assessment of the SSP program will require information from an extended follow-up period, several features of the SSP design make it useful to examine impacts at 18 months. Eligibility for the SSP supplement is contingent on initiating a supplement payment within one year after enrollment. Thereafter, participants can move in and out of full-time employment and continue to qualify for supplement payments whenever they meet the hours requirements of the program. These rules establish a strong incentive for program group members to find full-time employment by the twelfth month of the experiment, and suggest that any impacts observed near the end of the eligibility period may be close to an upper bound for later impacts on full-time employment. If the main effect of SSP is to speed the transition from welfare to work for those who eventually would find full-time employment anyway, then the program impacts will tend to dissipate over time as control group members "catch up." On the other hand, if those receiving the SSP supplement stay employed longer than they would have in the absence of the program, the impacts could grow over time. The expectation is that the main effect of SSP will be to speed the transition from welfare to work, so the impacts should dissipate somewhat over time.

For purposes of this paper, information collected in the baseline interview and 18-month survey is used to determine labor market status on a month-by-month basis from 10 months before program enrollment to 17 months after enrollment. ${ }^{16}$ Information is presented on five labor market outcomes: total monthly earnings; monthly hours of work; an indicator for any employment during the month (monthly hours of work greater than zero); an indicator for any full-time employment during the month; and an indicator for any part-time employment during

\footnotetext{
${ }^{16}$ The data are organized in "experimental" months, rather than calendar months, beginning with the month of random assignment. Complete labor market data for the first 17 months of the program are available for all but 10 sample members who responded to the 18 -month survey. These 10 sample members are excluded from the month 17 calculations.
} 
the month. Since SSP eligibility is predicated on working at least 30 hours per week, full-time employment is defined as working more than 130 hours in a month (30 hours per week times 4.33 weeks per calendar month), and part-time employment is defined as working 1 to 129 hours in a month. ${ }^{17}$

Data from IA and SSP administrative records are used to measure four program participation outcomes: an indicator for being on IA (receiving an IA payment during the month); average monthly IA payments; an indicator for being on either IA or SSP; and the sum of average monthly IA and SSP supplement payments. Since these data are taken from administrative records, information is available for a slightly longer time frame - up to 23 months after random assignment.

The data are summarized in two ways. First, a series of graphs shows average monthly outcomes for the program group and the control group, along with a monthly impact estimate. This estimate is simply the difference in average outcomes between the program group and the control group. Given the randomized design, this impact estimate should be a valid indicator of the program's effect. Also shown as a test of the random assignment procedure are the outcomes and estimated impacts for the 10 months before baseline. Under random assignment the program impacts in the months before baseline should be close to zero, and statistically significant only by chance.

In addition to the graphs of monthly outcomes, a table is presented showing employment and welfare outcomes based on quarterly averages of the monthly outcomes from the first quarter before baseline to the sixth quarter after the baseline. This table presents both unadjusted impact estimates and adjusted estimates based on regression models that include 18 baseline covariates and a dummy variable indicating membership in the program group. ${ }^{18}$ Because of the

\footnotetext{
${ }^{17}$ The requirement of 130 hours is potentially too strict because individuals who begin a full-time job typically work less than 130 hours in the month but can still receive a partial SSP payment.

${ }^{18}$ The covariates include the value of the dependent variable for the pre-baseline quarter; the respondent's age; number of children ages 0 to 5, 6 to 12, and 13 to 18; number of adults over age 18 in the household; an indicator
} 
randomized design, adjusting for the effects of baseline covariates is not necessary to obtain valid program estimates. However, the adjustment typically improves the precision of the estimated impacts.

All the outcomes and impact estimates reported in this section are based on the subsample of individuals who responded to the 18-month survey (that is, the sample described in Table 2). As we show in Section VII, below, an analysis of response patterns to the 18-month survey suggests that non-response biases may lead to a slight overstatement of the SSP impacts in this subsample. These potential biases should be kept in mind.

\section{B. Program Take-up}

Before presenting the impact estimates it is instructive to describe the extent of SSP participation among the 942 program group members eligible for the supplement. ${ }^{19}$ Program take-up is not the same as program impact because some program group members are "windfall" beneficiaries -- that is, they would have worked full time in the absence of SSP and for them the SSP supplement is simply a windfall. Indeed, the difference between the program take-up rate and the actual experimental impact on the full-time employment rate is an estimate of the size of the windfall group.

Figure 4 shows the fraction of the program group receiving SSP supplement payments during each of the first 23 months of the program. The participation rate grows steadily for the first 15 months, reaching a peak of 25 percent by month 15 . Thereafter, it drops off slightly and

18 (...continued)

for having ever worked before baseline; number of years of paid employment before baseline; dummy variables for being a high school graduate or having some education in excess of high school; a dummy variable indicating whether the respondent lived in subsidized housing at baseline; two dummy variables for the presence of physical or emotional problems at baseline; dummy variables for First Nation ancestry, European or Canadian ancestry, and Asian ancestry; and a variable indicating the number of months of IA receipt in the 36 months before baseline. In a few cases, data were missing for some of the covariates. These were replaced by sample means for the nonmissing cases. No regression-adjusted estimates are presented for quarter -1 because the outcome in quarter -1 is used as one of the regression control variables.

${ }^{19} \mathrm{~A}$ more extended discussion of program Lake-up is presented in Mijanovich and Long, 1995. 
stabilizes at around 20 percent from months 19 to 23 . Because the first SSP supplement payment could be received as late as month 14 , the drop-off after month 15 reflects job losses among those who had earlier qualified for the supplement.

We emphasize that the 25 percent take-up rate of the program group represents an upward bound on SSP's behavioral impact on full-time employment. Only if there are no windfall recipients is the behavioral impact on the full-time employment rate equal to the program take-up rate. To measure the true experimental effect we rely on the experimental design: under random assignment the experiences of the control group provide a valid counterfactual for the program group's behavior in the absence of SSP. Thus differences between the observed outcomes of the program and control groups measure the behavioral impact of the SSP subsidy. In the remainder of this section we examine these impacts on a variety of labor market and program-related outcomes.

\section{Unadjusted Monthly Impacts}

Figures 5 to 9 show the average monthly labor market outcomes for the program and control groups, along with the estimated SSP impacts in each month. Figures 10 to 13 present similar data for welfare-related outcomes. For reference, a vertical line in each graph separates the pre-baseline period from the post-baseline period. As noted earlier, if random assignment was successful, the program group and control group outcomes should coincide during the prebaseline period. Inspection of the figures shows that, with the exception of the part-time employment rate, the two groups' outcomes were virtually identical during the pre-baseline period. ${ }^{20}$

A cursory look at the figures reveals another striking pattern. With the exception of the part-time employment rate, all of the labor market outcomes show discrete jumps between month

\footnotetext{
${ }^{20}$ The part-time employment rate differences are statistically significant in 4 of the 12 months before baseline, while the overall employment rate differences are not statistically significant in any month before baseline. In the month just before baseline, neither outcome's difference is statistically significant.
} 
-1 and month 1. For example, in Figure 5, average monthly earnings of the control group rise about $\$ 50$, while those of the program group rise about $\$ 70$. The jumps in the labor outcomes around the baseline are much larger than the changes between any other pair of months, and are not reflected by a corresponding jump in IA participation. We suspect that the jumps are due to a "seam problem" arising from the fact that labor market data for month -1 are taken from the baseline survey, whereas labor market data for month 1 are taken from the 18-month survey.

To investigate the reasons for the "jump" in employment and earnings around the baseline period more fully, we calculated the number of new jobs starting in each month. This exercise revealed an unusually large number of new jobs coded as starting in month 1 . There are two explanations for this phenomenon. One is that respondents were more likely to report "underthe-table" jobs in the 18-month survey than in the baseline survey, leading to apparent job starts in month 1 for jobs that were really held at baseline. Another is that recall errors, in combination with particular features of the 18-month computer-assisted interview program, led to measured job starts in month 1 for jobs that actually started somewhat later. Since there is no evidence of a larger (or smaller) jump for program group members relative to control group members, however, we believe that the impact estimates are largely unaffected by this apparent seam problem.

The patterns for the control group in Figures 5 to 8 reveal a more-or-less steady trend toward greater labor market activity in the months following baseline. This trend is clearly accelerated among the program group. The earnings impacts (Figure 5) are statistically significant from months 5 through 17 and increase gradually from about $\$ 40$ in month 5 to a peak of about $\$ 140$ in month 14 . This is a sizeable impact (roughly 60 percent) relative to mean earnings of the control group in the same month. During the last three months of the observation window, the earnings of the program group dip slightly, while those of the control group continue to rise, implying a decline in the estimated program impact to around $\$ 100$ per month in month 17 (or roughly a 40 percent program-control group difference). Because eligibility for 
the SSP supplement ended at month 12, the employment impacts between months 10 and 14 may be the largest impacts that will occur during the demonstration period.

Hours of work follow a pattern similar to earnings. The hours impacts (Figure 6) are statistically significant in months 5 through 17, and rise gradually from around 6 hours per month in month 5 to 21 hours in month 14. Again, this is a sizeable impact (about a 70 percent increase) compared to the mean hours of the control group. As with earnings, average hours of work of the program group fall off after month 14 , while hours of work of the control group rise, leading to a 15 -hour difference by month 17 . If the earnings impacts are divided by the corresponding hours impacts, the ratio tends to fall between $\$ 6.50$ and $\$ 7.00$. This suggests that program group members are taking fairly low-paying jobs - only $\$ 1.00$ to $\$ 2.00$ per hour above the minimum wage. In Section VI, below, more detailed information is presented on the wage effects of the SSP program.

The overall employment rate (Figure 7) follows a pattern similar to earnings and hours. The employment impacts are statistically significant from months 6 through 17 and rise gradually to a peak impact of 14 percentage points in month 14 before falling slightly. As shown in Figures 8 and 9, almost all of this impact is accounted for by a rise in full-time employment and a drop in non-employment. Although simple economic models suggest that the SSP program might reduce part-time work, this is not the case for the definition of part-time work depicted in Figure 9. Other classifications of full- and part-time work based on a less stringent hours criterion show a slightly more negative impact on part-time employment.

A comparison of SSP take-up rate among the program group with the experimental impact on the full-time employment rate (i.e., figure 4 versus figure 8) suggests that a sizeable fraction of SSP participants are "windfalls". For example, the impact estimate in month 15 is 15 percent while the take-up rate is 25 percent, implying that 10 percent of the program group received windfall benefits from SSP. Thus, roughly three-fifths of SSP participants in the program group were responding to the financial incentive, while about two-fifths would have worked full time 
anyway.

In light of the 30-hour-per-week threshold imposed by the SSP eligibility rules, it is interesting to ask whether there is a "clustering" of hours among SSP participants at exactly the minimum level required for eligibility. ${ }^{21}$ Throughout the entire post-baseline period, 21 percent of program group members who were employed full time (i.e., working at least 130 hours per month) averaged exactly 30 hours of work per week, compared to 13 percent of full-time control group members. ${ }^{22}$ An additional 18 percent of program group members who were employed full-time worked exactly 35 hours per week, compared to 12 percent of control group members. Overall, some 60 percent of program group members who were employed full time worked less than 40 hours per week, while only 45 percent of the control group members who were employed full time worked less than 40 hours per week. Thus, there is some indication that program group members are clustering at or near the 30-hour threshold, but a substantial number are also working more.

As shown in Figures 10 and 11, the impacts of the SSP program on IA receipt and average IA payments mirror the impacts on employment. ${ }^{23}$ From months 4 through 17, average IA payments and the IA receipt rate decline faster for program group members than for control group members. By month 17, the average IA payment for program group members is about $\$ 130$ less than the average IA payment for control group members. Thereafter, the difference closes slightly. The percentage of program group members who have left IA reaches a peak of about 33 percent in month 17, and then levels off between months 18 and 23. By comparison, the percentage of the control group who have left IA follows a fairly steady upward trend. Thus,

\footnotetext{
${ }^{21}$ An analysis of federal and provincial tax and transfer program interactions with the SSP program suggests that a substantial fraction of program group members face very high marginal tax rates when they work more than 30 hours per week. If individuals can freely choose their hours of work, this should lead to a concentration of hours at exactly the minimum eligibility level.

${ }^{22}$ Note that such conditional comparisons must be interpreted very carefully, and are not in general valid estimates of the causal effect of the SSP program.

${ }^{23}$ Note that the IA status variable in Figure 11 is defined in terms of not receiving IA to permit easier comparison with the employment outcomes.
} 
SSP's impact on IA recipiency peaks in month 15 , and falls back to about 10 percentage points by months 21 to 23 . Because labor market information is not yet available beyond month 17 , we cannot determine whether the employment-related impacts exhibit a parallel decline after month 18.

Our final program impact concerns the sum of IA benefits and SSP supplement payments. This combined outcome is of interest for at least two reasons. First, the sum of IA benefits and SSP payments provides useful information about the overall cost of the SSP program. An important question for the viability of SSP is whether the savings in welfare benefits generated by the program are offset by the costs of the supplement. Second, a comparison of the SSP impact on receipt of IA and its impact on the receipt of IA plus SSP provides another measure of the relative size of the windfall group. In the absence of any windfalls, the number of people who take up SSP will be equal to the number who are induced to leave IA, and the fraction of people who receive either IA or SSP in the program group will equal the fraction who receive IA in the control group. If some supplement recipients would have moved off IA anyway, then the fraction who receive either IA or SSP in the program group will exceed the fraction who receive IA in the control group.

As shown in Figure 12, the sum of average IA and SSP payments for the program group is higher than average IA payments for the control group throughout the first 23 months of the experiment. Moreover, the percentage of people receiving IA or SSP in the program group is consistently higher than the percentage on IA in the control group (Figure 13). These findings suggest that a sizeable percentage of people (roughly 10 percent by month 20 ) receive supplement payments under SSP, but would have moved off IA even in the absence of the program. Supplement payments for this windfall group add to the costs of SSP without any corresponding reduction in IA benefits. Consequently, by the second year of the experiment, average costs for IA and SSP benefits in the program group are $\$ 80$ to $\$ 100$ dollars per month higher than the average cost for IA benefits alone in the control group. A good portion (but not all) of these 
higher average costs are windfall benefits.

It is worth noting that the combination of higher earnings and higher combined IA and SSP payments among the program group imply substantially higher gross incomes than in the control group. For example, in month 15 , members of the program group had about $\$ 235$ more in monthly eamings and SSP/IA payments than members of the control group. This is a substantial relative gain - roughly 23 percent of mean total earnings and IA benefits for the control group. Thus, by month 15 , SSP was having a substantial anti-poverty effect.

\section{Unadjusted and Adjusted Quarterly Impacts}

We turn now to a brief overview of the quarterly program impacts, and a comparison of the unadjusted and adjusted impacts. Table 3 (panels $A$ to I) presents quarterly averages of the labor market and welfare-related outcomes of the control and program groups, along with unadjusted and adjusted quarterly impacts. ${ }^{24}$ The first thing to note about these results is the similarity between the unadjusted and adjusted impacts. The regression adjustments lead to some modest increase in the precision of the impact estimates (lower standard errors), but have little or no effect on the estimates themselves (with one exception noted below). A second thing to note is that none of the unadjusted impacts in the quarter before random assignment (quarter -1) are statistically significant. ${ }^{25}$ In fact, in only one case does the unadjusted impact in quarter 1 exceed its standard error.

The unadjusted and adjusted employment, earnings, and hours impacts (panels $\mathrm{A}$ to $\mathrm{C}$ ) all peak in quarter 5 (months 13 to 15) and are statistically significant at the 5 percent level from quarters 3 to 6 . The maximum employment impact is 12 to 13 percentage points (about 40 percent of the control group mean), the maximum monthly earnings impact is $\$ 137$, and the maximum hours impact is 20 hours per month. The impacts on full-time employment (panel D)

\footnotetext{
${ }^{24}$ The quarterly outcomes are simple averages of the underlying monthly figures, expressed as a monthly rate.

${ }^{25}$ Adjusted impacts for quarter -1 are not computed because one of the covariates is the quarter -1 value of the dependent variable.
} 
are virtually identical to the impacts on overall employment, but are much larger as a percentage of the control group outcome. For example, the full-time employment impact in quarter 5 is about 13 percentage points (or just over 100 percent) of the control group mean for the quarter.

Although the unadjusted impacts on part-time employment (panel E) are generally small and statistically insignificant, the adjusted impacts are uniformly negative and are actually statistically significant in quarters 2 and 6 . Here, adjustment for the effects of covariates (mainly, the part-time indicator for the pre-baseline quarter) makes a slight difference with respect to inferences about the effect of the SSP program.

As suggested by Figure 11, the estimated impact of SSP on the IA receipt rate rises throughout the first year and a half of the experiment (see panel $F$ of Table 3), reaching close to 14 percentage points by quarter 6 . Similarly, the impact on the average amount of IA benefits received (see panel G) rises steadily, ending with a net impact of $\$ 135$ (or 18 percent of the control group mean). Nevertheless, the presence of individuals who receive SSP but would have moved off IA anyway results in a total combined receipt rate for IA and SSP that is actually 9 to 10 percentage points higher in the program group than in the control group (in panel $\mathrm{H}$ ). The estimated adjusted impacts on average IA and SSP costs (panel I) are $\$ 66$ to $\$ 90$ per month in quarters 4 to 6 of the experiment.

\section{Variation in the Impacts of SSP by Program Generosity}

\section{A. Measures of SSP Generosity}

Even though the SSP demonstration is built around a single treatment, there are substantial differences in the "generosity" of the SSP program across individuals in the research sample. This variation arises for several reasons. First, individuals with higher wages receive lower SSP benefits for the same amount of work (although their total income is higher). For example, an individual in British Columbia working 30 hours per week at the minimum wage of $\$ 6.00$ per hour receives a monthly subsidy of $\$ 1,156$ (with total monthly income of $\$ 1,935$ ), whereas an 
individual who earns $\$ 10.00$ per hour receives a monthly subsidy of $\$ 899$ (with total monthly income of $\$ 2,198$ ). Second, because of different SSP target earnings levels in the two provinces, two individuals with the same wage will receive a higher supplement in British Columbia than in New Brunswick. Third, the generosity of the SSP program relative to IA varies across single parents because of variation in IA benefit rates by province and family size. Since most people would be on IA in the absence of the SSP supplement offer, the difference in net incomes between SSP and IA is a key determinant of behavioral responses to the program. Finally, the relative generosity of SSP depends on individual-specific circumstances, such as child support payments and non-wage income sources. ${ }^{26}$

To assess the degree of variation in the generosity of the SSP supplement, we calculated two measures of relative generosity. The first is based on a simple comparison between the total earnings and supplement payments that an individual would receive working 30 hours per week on SSP, versus the maximum monthly IA payment (based on family size and province of residence) that an individual would receive if not working. This measure makes no adjustments for provincial or federal taxes or child tax credits, or for differences in other transfers that would arise by moving off IA. The second, more sophisticated measure is based on the estimated difference in net incomes between working 30 hours per week on the SSP program and working 30 hours per week on IA. This measure takes into account the differences in federal and provincial taxes, refundable child tax credits, and child care subsidies, using detailed tax tables and individual-specific information on family size, alimony and child support payments, and other income sources. For simplicity, the second measure is estimated under the assumption that British Columbia sample members would receive the standard earnings disregard ( $\$ 200$ per

\footnotetext{
${ }^{26}$ IA benefits are reduced dollar-for-dollar by child support payments and by income from other family members, whereas SSP benefits are independent of non-wage income or the incomes of other family members. Another source of potential variation in relative generosity arises for people living in social housing, for which rent formulas exclude IA income but include earnings and SSP income. For the sample and time period analyzed in this paper, however, SSP subsidies were excluded from the calculation of social housing rent.
} 
month) if on IA. ${ }^{27}$

Both generosity measures require an estimate of the gross hourly wage for individuals in the research sample. Observed wages for sample members who worked in the pre-baseline period (months -1 to -12 ) were used to estimate a standard human capital wage equation. We employed a standard two-step selection procedure to account for possible non-randomness in the subset of pre-baseline workers. Predicted wages were then assigned to all program group and control group members, with the minimum wage assigned for anyone whose predicted wage was below the provincial minimum wage. ${ }^{28}$

Table 4 presents an overview of the altemative generosity measures. An initial analysis revealed that much of the systematic variation in either generosity measure is accounted for by only two factors: the province of residence, and whether an individual has one or more than one dependent child. ${ }^{29}$ Based on this fact, data are presented for the four province/family size subgroups shown across the columns of the table. Note that the groups based on family size within each province are about equal in numbers (see the last row of the table).

Rows 1 and 2 of Table 4 show average predicted wages for each province/family size subgroup, and the fraction of wage predictions within $\$ 1.00$ of the provincial minimum wage. Predicted wages in New Brunswick are about 25 percent lower than in British Columbia, and are more highly concentrated just above the minimum wage. Row 3 shows the fraction of each group who were working at baseline. This is fairly similar across subgroups, although sample members in New Brunswick with one child have a slightly higher baseline employment rate than the other groups.

Rows 4 through 7 present information on the simple generosity measure, which compares

\footnotetext{
${ }^{27}$ Details of the calculations are available from the authors on request.

${ }^{28}$ Individuals working in subminimum wage jobs do not qualify for an SSP supplement. Details of the wage imputation procedure are available from the authors.

${ }^{29}$ Two-thirds of the variation in the simpler generosity measure and 45 percent of the variation in the more complex measure is explained by these variables. The correlation of the two generosity measures across individuals is 0.68 .
} 
gross pay on SSP at 30 hours of work per week to the statutory IA benefit, assuming zero hours of work. A comparison across subgroups reveals that while IA benefits are higher for larger families (especially in British Columbia), predicted earnings and SSP supplements are about the same. Thus, the relative generosity of the SSP program is smallest for larger families in British Columbia. In absolute terms, SSP is most generous for families with one child in British Columbia. If generosity is expressed as a fraction of the basic IA benefit level, however (as in row 7), SSP is most generous for small families in New Brunswick.

Rows 8 to 10 present similar information using the more complex generosity measure based on net (that is, after tax and transfer) income comparisons at 30 hours per week. Consideration of taxes and transfers leads to a notable reduction in the apparent generosity of the SSP program across family size categories, mainly because of the higher transfers and tax credits available on IA. ${ }^{30}$ Nevertheless, the ranking of relative generosity across the four family size/province subgroups is similar: SSP is least generous for single parents with two or more dependents in British Columbia, and most generous for single parents in New Brunswick with one child.

\section{B. Variation in SSP Impacts}

In light of the variation in relative generosity of the SSP program by province and family size, and the theoretical prediction from simple labor supply models that the SSP impact should vary by the relative generosity of the program, it is interesting to compare SSP impacts across provinces and within provinces between individuals with larger and smaller families. As a first step in this comparison, statistical tests were performed to determine whether the SSP impacts on the outcomes analyzed in Table 3 were different for British Columbia and New Brunswick. In no case were the differences statistically significant, although the labor market outcomes

\footnotetext{
${ }^{30}$ Even accounting for taxes and transfers, SSP yields a higher net income than IA (at 30 hours of work per week) for all but a bandful of individuals with very large families in British Columbia.
} 
exhibit somewhat different patterns over time for program and control group members in the two provinces. Specifically, whereas earnings of the British Columbia control group rise steadily from baseline, eamings of the New Brunswick control group show a pronounced "dip" between months 7 and 14. One explanation for this pattern is the highly seasonal nature of employment in this province. ${ }^{31}$ Among the program group in New Brunswick, however, there was no evidence of such a dip, suggesting that the program group may have taken more stable jobs to ensure continuing supplement eligibility.

Although average SSP impacts are not very different between British Columbia and New Brunswick, a closer look at the differences by family size in the two provinces reveals an interesting pattem. Table 5 summarizes the average monthly labor market impacts by quarter for the four family size/province subgroups. For simplicity's sake, only unadjusted program impacts for three key outcomes are reported: average hours of work, average earnings, and the overall employment rate. ${ }^{32}$ Despite the fact that SSP is least generous for individuals in British Columbia with larger families, the data in Table 5 suggest that the program had its largest impact on this subgroup. Indeed, the earnings, hours, and employment impacts in quarters 5 and 6 for single parents with two or more dependent children in British Columbia are roughly twice as large as the corresponding impacts for any other subgroup. ${ }^{33}$ While not shown in the table, the larger labor market impacts for this subgroup are partially reflected in lower welfare participation rates. In quarter 6, the (unadjusted) difference in the percentage on IA between the program group and the control group is -19.1 percent for the British Columbia subgroup with

\footnotetext{
${ }^{31}$ Intake for the New Brunswick research sample was concentrated in the period from November 1992 to April 1993. Hence, experimental months 7 to 14 correspond (on average) to calendar months August 1993 to April 1994.

${ }^{32}$ Impact estimates derived from regression models similar to the ones used for the adjusted impacts in Table 3 are very close to the unadjusted impacts. Outcomes of the program group and control group in each province/family size subgroup were also checked to determine whether they differed in the pre-baseline quarter: In all cases, differences are small and statistically insignificant.

${ }^{33}$ Formal tests of the bypothesis that the SSP labor market impacts are the same for larger British Columbia families as for all other subgroups are rejected at the 5 percent level for quarters 5 and 6.
} 
two or more children, versus an average impact of -13.8 percent (see Table 3, panel F). ${ }^{34}$

In light of the relatively small sample sizes in the first cohort of the SSP research sample, it is difficult to reach any strong conclusions about the variation in program impacts across subgroups. By the same token, the SSP demonstration was not explicitly designed to test the effects of different generosity levels, and the variation in generosity induced by family size and interprovincial differences is limited. Nevertheless, we tentatively conclude that there is no strong relationship between simple measures of program generosity and the magnitude of the program impacts. If anything, the program responses seem to be largest for British Columbia parents with more children, a group for whom the SSP program is relatively less generous than conventional IA. It will be interesting to see whether these conclusions continue to hold over longer time frames, and for the entire SSP sample.

\section{Measuring Wage Outcomes Associated with SSP}

Having measured significant employment responses to the SSP incentive, it is interesting to try to characterize the wages of the "net jobs" generated by the program. Conventional models of the work-welfare decision suggest that these net jobs should be disproportionately drawn from the low end of the wage distribution. According to these models, individuals who face relatively low-wage opportunities are further from the margin between working and staying on welfare, and are less likely to work in the absence of a supplement. By comparison, individuals with better wage opportunities might be expected to leave IA even without the SSP supplement: For them, the SSP program is more likely to serve as a windfall. Empirical confirmation of these predictions would provide some evidence that low wages are a primary reason for continuing welfare participation. It is also interesting to ask whether program participants who are induced to work by the SSP supplement will move up the wage distribution

\footnotetext{
${ }^{34}$ The difference in the impact of SSP on larger British Columbia families versus its overall impact on IA participation in quarter 6 is just significant at the 5 percent level.
} 
as they accumulate work experience. With the limited data currently available, only a preliminary look can be taken at this important question. In subsequent research, data will be used over a longer time frame to study the extent of wage progression among supplement takers.

Table 6 presents a variety of comparative information on the distributions of wages among the program group and the control group. To handle interprovincial wage differences using the pooled sample, wages are normalized relative to the minimum wage in the appropriate province. For example, a wage of $\$ 6.50$ is $\$ 1.50$ above the minimum wage of $\$ 5.00$ in New Brunswick, but only $\$ .50$ above the minimum wage of $\$ 6.00$ in British Columbia. Using this approach, wage outcomes were divided into six categories: missing wage; ${ }^{35}$ less than the minimum wage; up to $\$ .99$ above the minimum wage; $\$ 1.00$ to $\$ 1.99$ above the minimum wage; $\$ 2.00$ to $\$ 2.99$ above the minimum wage; and more than $\$ 3.00$ above the minimum wage. The resulting wage distributions for month 13 (that is, the first month after the close of the eligibility period for program group members to initiate a supplement) and month 17 (the last month for which data are available) are shown in Table 6.

The first row of each panel shows the percentages of individuals in the program group and control group who were not working. In the overall sample, 58.8 percent of the program group were not working in month 13 , compared with 72.4 percent of the control group. The difference -13.6 percentage points $\rightarrow$ is the unadjusted program impact on the employment rate. The remaining rows of the table pertain to specific wage intervals, including the missing wage category (row 2). A comparison of columns 1 and 2 shows the "excess fraction" of jobs for the program group in a particular wage interval. ${ }^{36}$ For example, in month $13,13.9$ percent of the program group held a job that paid up to $\$ .99$ above the minimum wage $(\$ 6.00$ in British Columbia and $\$ 5.00$ in New Brunswick), compared with 5.8 percent of the control group. The difference (8.1 percentage points) is an estimate of the SSP program effect on the percentage of

\footnotetext{
${ }^{35}$ Information on wages was missing for some individuals who may have been working in casual or piece-rate jobs with compensation that cannot be easily converted to an hourly wage.

${ }^{36}$ Note that fractions in each wage interval reflect all individuals, not just those who held a job.
} 
people who held a minimum-wage-to-\$.99-above-the-minimum wage range in month 13 .

By construction, the sum of the differences in each wage interval between the program group and the control group is equal to the overall difference in employment rates between the groups. Dividing the difference in the percentage employed in a particular wage interval by the overall difference in employment rates therefore gives the fraction of "net jobs" created by the SSP supplement in that wage interval. For example, in month 13, jobs in the minimum-tominimum-plus-\$.99 range interval accounted for 8.1 percentage points of the total 13.6 percentage point increase in employment, or 59.6 percent of the net jobs. Following this procedure, the distribution of net jobs was constructed across all the wage intervals, as shown in column 3 of Table $6 .{ }^{37}$ Note that there can be a negative entry in this column if a smaller fraction of program group members than control group members hold jobs in a given wage interval. This may happen if the SSP supplement induces some people who would have held a job in a particular wage interval to find a job in a different wage interval. For example, someone in New Brunswick may forgo a relatively high-wage job in the fishing industry for a steadier low-wage job in the service industry, to ensure her continuing eligibility for SSP.

If the SSP program generates jobs that are "just like" those held by workers in the control group, then the distribution in column 3 will be equal to the conditional distribution of wages for workers in the control group. On the other hand, if the SSP program induces some people with relatively low-wage opportunities to find jobs, then the distribution in column 3 will have more jobs in low-wage intervals than the distribution of wages for working controls. Column 4 gives the difference between the fraction of net jobs attributable to SSP in a particular wage interval (that is, column 3) and the fraction of control group jobs in the same interval (that is, the entry in column 2 divided by the fraction of control group members with a job).

\footnotetext{
${ }^{37}$ Formally, let $f_{j}^{c}$ represent the fraction of the entire control sample in wage interval $j$ (including non-workers). Similarly, let $f_{j}^{\mathcal{P}}$ represent the fraction of the program group in interval $j$. Finally, let $f{ }_{0}^{c}$ and $f g$ represent the non-working fractions of the control group and program group. Then the fraction of net jobs attributable to jobs in wage interval $j$ is $\left(f_{j}^{p}-f_{j}^{c}\right) /\left(f_{0}^{c}-f_{g}\right)$. Standard errors for this fraction can be constructed by the delta method.
} 
The results for month 13 suggest that about 60 percent of the net jobs attributable to SSP paid within $\$ .99$ per hour of the minimum wage, and another 30 percent paid from $\$ 1.00$ to $\$ 1.99$ per hour above the minimum wage. These wages are relatively low compared to the distribution of wages for control group members who were working in the same month, of whom 36 percent were earning at least $\$ 3.00$ per hour above the minimum wage. ${ }^{38}$ Consistent with the predictions from simple economic models of welfare participation, it seems that individuals who are induced to move off IA and into employment by the SSP supplement tend to be those with relatively low-wage opportunities.

There is no evidence of a program effect on the probability of holding a job that pays less than the minimum wage, which is reassuring since individuals holding jobs below the minimum wage are ineligible for a supplement. However, the SSP program seems to lead to a modest reduction in the fraction of individuals with a missing wage. One explanation for this apparent effect on missing-wage jobs is that SSP eligibility rules lead some workers who would otherwise work in casual or piece-rate jobs with compensation that cannot be easily converted to an hourly wage to find jobs for which hourly wages can be easily calculated. Similarly, it is possible that the SSP supplement leads program group members to choose lower-wage jobs - perhaps because higher-wage jobs have less predictable hours. In any case, the sampling errors for the percentage of net jobs in the missing-wage category are relatively large, so any apparent shortage of such jobs among the program group must be interpreted cautiously.

The wage distributions for month 17 (the last month for which labor market data are available) are fairly similar to the distributions for month 13 . In comparing these distributions, it must be kept in mind that while the net employment impact of SSP in month 13 was 13.6

\footnotetext{
${ }^{38}$ This comes from dividing the 10.0 percent of control group members eaming $\$ 3.00$ or more above the minimum wage by the percentage of working control group members (27.6 percent), yielding 36.2 percent of working control group members earning at least $\$ 3.00$ above the minimum wage.
} 
percent, the net impact in month 17 was only 7.5 percent. A smaller fraction of the program group was working in month 17 than in month 13, whereas a slightly larger fraction of the control group was working in the later month. Although it is possible that these changes might have caused a rightward shift in the distribution of wages for the net jobs attributable to the SSP program, this does not appear to be the case. ${ }^{39}$ There is certainly no evidence of relative wage progression in the program group between months 13 and 17 . Of course, the four-month difference is probably far too short to measure any reasonable degree of wage progression. ${ }^{40}$

Two main conclusions can be drawn from these analyses. First, wages for the jobs that can be attributed to the SSP supplement tend to be clustered near the bottom of the wage distribution. This pattern is consistent with conventional economic models of welfare participation that suggest that many individuals rationally choose to receive IA rather than work because their wage opportunities are relatively constrained. Second, based on the very limited comparison of months 13 and 17 after random assignment, no evidence is found that the distribution of wages for the net jobs attributable to the SSP program has shifted upward over time.

\section{Evaluating the Effect of Non-Response to the 18-Month Survey}

Up to this point our analyses have been conducted on the subset of the SSP research sample who completed the 18 -month survey. As noted earlier, about 10 percent of the sample either could not be located or refused to respond to the survey. Although no survey-based data are available for the non-respondents, IA and SSP administrative records allow comparisons between people who responded to the 18 -month survey and those who did not. In this section,

\footnotetext{
${ }^{39}$ If larger SSP employment impacts are generated by drawing more low-wage workers into employment, then the net jobs attributable to the program will have lower wages in periods with a larger employment impact. On the other hand, the additional control group members employed in month $17 \mathrm{might}$ have had higher-than-average wages, so that month 17 has both a smaller impact and a greater percentage of net jobs in the low-wage intervals.

${ }^{40} \mathrm{Based}$ on conventional estimates of human capital earnings functions, one might expect only a 2 to 5 percentage point increase in wages for each year of experience in the labor market, or less than a percentage point of wage growth in four months.
} 
the patterns of non-response are described and an attempt is made to evaluate the effects of nonresponse bias on the estimates of the SSP program impacts.

\section{A. Analysis of Response Rates}

Table 7 shows the percentages of individuals in the first cohort of the SSP research sample who completed the 18-month survey, by research group, by province, and by whether the individual was receiving LA payments in month $18 .^{41}$ Row 1 of the table contains response rates for the overall sample and for the control and program groups. As shown in column 4, the control group had a 3.3 percentage point higher response rate, and this difference is statistically significant at conventional levels. Response rates were slightly higher in New Brunswick than in British Columbia (see rows 2 and 3), although the difference in response rates between the program group and the control group was very similar in the two provinces.

Different response rates for the program group and the control group do not necessarily imply any bias in the comparison of outcomes between respondents in the two groups. Indeed, if response probabilities were constant within groups and independent of other characteristics, then the differences in measured outcomes of the survey respondents would provide unbiased estimates of the true program effect. As shown in rows 4 to 6 of Table 7, however, response rates within the program and control groups vary by IA status at the time of the survey. Within the control group, IA recipients at month 18 were more likely than non-recipients to respond to the survey. Within the program group, however, IA recipients and non-recipients had about the same response rates. Since IA recipients are over-represented among controls in the respondent subsample, but not among the program group in the respondent subsample, the gap in IA receipt rates between the program and control groups in the respondent subsample overstates the true

\footnotetext{
${ }^{41}$ Note that IA and SSP administrative data are used for both respondents and non-respondents to the 18 -month survey. The results in Table 7 are very similar if response rates are compared by IA status in any particular month between 15 and 20 months after random assignment.
} 
difference for the entire sample. ${ }^{42}$

The higher response rate for IA recipients over non-recipients in the control group could be due to a number of factors, including: (1) Some non-IA recipients may have moved out of province, whereas IA recipients are all in-province; (2) IA recipients are less likely that to have undergone a change in their living arrangements or labor market status, making it less likely that they have changed addresses within province; (3) non-IA recipients may feel less obligation to respond to a survey than those who are still receiving IA. In principle, all of these factors should have a similar effect on relative response rates in the program group. On the other hand, two other considerations may depress the relative response rate of IA recipients in the program group. First, since the SSP supplement moves some people from welfare to work, those who remain on IA may be disproportionately unresponsive to the request for information (a "selection" effect). Second, because individuals in the program group were repeatedly contacted with information about the supplement, those who remained on IA may have become tired of defending their choice (a "harassment" effect). ${ }^{43}$

While it is difficult to precisely measure the relative contributions of the selection and harassment effects, a lower bound on the harassment effect can be calculated by assuming full response among the select group leaving IA for SSP. In other words, suppose that all the people in the program group who were moved off IA by the SSP program would have responded to the 18-month survey. Based on the IA receipt rate in the control group, this would account for an

\footnotetext{
${ }^{42}$ Formally, let $p(I A \mid C)$ and $p(I A \mid E)$ represent the probability of IA receipt among the control and program groups. The true experimental impact on IA receipt is $p(I A \mid E)-p(I A \mid C)$. Let $R$ denote the event of responding to the 18-month survey. Then the measured impact in the respondent subsample is $p(I A \mid R, E)-p(I A \mid R, C)=p(I A \mid E) * p(R \mid I A, E) / p(R \mid E)-p(I A \mid C) * p(R \mid I A, C) / p(R \mid C)$. Since response rates for $I A$ recipients and non-recipients are about equal in the program group, $p(R \mid I A, E) / p(R \mid E) \approx 1$, while $p(R \mid I A, C) / p(R \mid C)>1$, implying a downward bias (that is, a larger negative response) in $p(I A \mid R, E)$ - $p(I A \mid R, C)$ relative to $p(I A \mid E)$ - $p(I A \mid C)$.

${ }^{43}$ Alternatively, some program group members who tried unsuccessfully to find full-time employment may have become so discouraged that they refused to be interviewed.
} 
additional 124 respondents on IA in the program group, ${ }^{44}$ implying an overall response rate of 90.2 percent for program group members who would have been on IA in the absence of the program. Since the response rate in the control group for IA recipients was 93.3 percent, a "lower bound" estimate is that the harassment effect reduced the response rate for IA recipients in the program group by 3.1 percentage points.

Further analysis of response rates for members of the program group who were not on IA reveals that those who received a supplement payment in month 18 had a relatively high response rate (94.5 percent). Averaging the response rates for IA recipients and SSP supplement takers, the overall response rate for program group members who received any form of payment (either SSP or IA) was 89.8 percent. By comparison, the response rate for those who received neither IA nor a supplement payment was 78.9 percent. The relative response rate for program group members who received any form of payment (IA or SSP) versus those who received nothing is therefore similar to the relative differential for IA recipients and non-recipients in the control group: For both groups, people who received some form of payment are over-represented in the respondent subsample. It follows that the estimated program impact for total receipt (IA plus SSP) in the respondent subsample is an overestimate of the true program impact.

\section{B. Assessing the Sign and Magnitude of Non-Response Bias}

Because IA and SSP supplement payment data are obtained from administrative records, non-response in the 18-month survey is not a problem for estimating the impact of the SSP supplement on the IA and SSP outcomes. For such outcomes as the probability of working, however, the 18-month survey is the only source of data. Furthermore, since IA and SSP supplement status are mechanically correlated with labor market outcomes, and since response rates vary by program status and IA/SSP supplement status, one might expect response rates to

\footnotetext{
44 The IA receipt rate in the control group in month 18 was 0.7917 , while the rate in the program group was 0.6754 . Since the control group sample comprises 1,066 individuals, $124\left(=1,066^{*}[0.7917-0.67545]\right)$ people were moved off IA by the program.
} 
vary by program status and employment status, leading to biases in the estimated program impacts for all the labor market outcomes discussed in Section IV.

One way to evaluate the effect of this bias is to assume that response rates for the 18month survey depend only on program status and IA or SSP supplement status as of month 18. It is then possible to simply "reweight" the labor market outcome data for each subgroup (say, control group members who were on IA in month 18) by the inverse of their response probabilities, and calculate adjusted estimates of the mean labor market outcomes for the program group and the control group. While this assumption is probably too strong, it nevertheless captures some of the measurable variation in response rates, and gives some indication of the likely sign and magnitude of non-response bias.

Table 8 illustrates the application of this idea to the observed IA and combined IA and SSP receipt rate outcomes of the program and control groups. For each quarter, three estimates of a particular outcome are presented: an estimate based on the overall sample, including nonrespondents to the 18-month survey (labeled the "all" sample); an estimate based on the unweighted average for respondents to the 18-month survey (labeled the "unweighted" sample); and an estimate based on a weighted average of the data for respondents to the 18-month survey (labeled the "weighted" sample). The inverse response probabilities are used as weights for six groups defined by IA and SSP status in month 18: control group members on IA; control group members off IA; program group members on IA who did not receive an SSP supplement payment; program group members who were off IA and received an SSP supplement payment; program group members who received both IA and an SSP supplement payment; and program group members who received neither IA nor an SSP supplement payment.

The first half of the table shows the percentages receiving IA in each quarter and the estimated program impacts. As expected given the response patterns in Table 7, the unweighted averages from the 18-month survey respondents overstate the fraction of IA recipients in the control group in quarters 1 to 6 , leading to downward-biased estimates of the program impacts. 
The weighting procedure "corrects" the IA receipt rates for non-response biases and gives rise to program impacts that are very close to the estimates based on the full sample.

In general, the same basic pattem emerges in the second half of the table, where data are presented on combined IA and SSP receipt. The weighted averages using only the survey respondent subsample tend to be closer to the overall averages than the simple unweighted averages. However, the estimated program impacts based on the unweighted averages for the respondent subsample tend to be slightly closer to the averages based on the full sample. The non-response biases in the unweighted means for the program and control groups effectively "difference out," leading to almost no bias in the program impacts from the unweighted data.

Table 9 shows what happens when the same weighting procedures are applied to two of the estimated labor market outcomes (employment and earnings). In these cases, however, no estimates are available from the overall sample to compare against the weighted or unweighted averages from the respondent subsample. The weighting adjustments tend to raise the average outcomes for the control group members and lower the average outcomes for the program group members, leading to slightly smaller program impacts than arise from the unweighted data. These adjustments reflect the patterns of non-response in the two groups. In the control group sample, people who are off IA are under-represented. Since these tend to be people with better labor market outcomes (more hours, higher earnings), the weighting adjustment raises the mean outcomes for the control group. In the program group sample, however, people who are on IA have relatively low response rates (no higher than those off IA), while those who are receiving an SSP supplement have very high response rates. Since people who receive a supplement are necessarily working full time, the weighting adjustment lowers the hours, earnings, and employment rate of the program group. The net effect of the two adjustments lowers the estimated program impacts on the probability of working, average monthly hours, and average monthly earnings by about 10 percent.

Two main conclusions can be drawn based on this analysis. First, experimental impacts 
derived from the subsample who responded to the 18 -month survey overstate the effect of the SSP supplement on IA receipt rates, but (very slightly) understate the effect of the supplement on the combined IA and SSP receipt rate. Second, and more tentatively, non-response biases in the 18-month survey probably lead to an overstatement of the SSP supplement's net impact on labor market outcomes such as the probability of working or earnings. The magnitude of the bias is perhaps 10 percent. Thus, if the measured impact on the probability of working, using the 18-month survey data, is 11 percentage points, the true impact is probably about 10 percentage points.

\section{Conclusions}

As in most other countries, welfare expenditures and caseloads in Canada have risen over the past several decades, placing growing fiscal strains on federal, provincial, and local governments. It has long been argued that a key to reducing welfare dependency is to provide gainful employment opportunities for welfare recipients. Previous efforts at stimulating employment have utilized a variety of approaches, most of which have enjoyed moderate success. In this paper, we have presented early findings from a unique social experiment being conducted in two very different sites in Canada (lower mainland British Columbia and southern New Brunswick) that offers a generous financial incentive for long-term welfare recipients to find a full-time job and leave welfare. To our knowledge, this is the first time such an approach has been subjected to a formal test and evaluation.

The early findings from the Self-Sufficiency Project indicate that a significant number of single parents respond to the program's financial incentives by taking full-time jobs. In fact, after 14 months, the fraction of welfare recipients working full time among those who were offered the SSP earnings supplement is about twice that of a randomly assigned control group. There is no strong evidence that the impact of the SSP supplement differs systematically by the generosity of SSP relative to the alternative of remaining in the IA program, although small 
sample sizes and the "single treatment" design of the demonstration make it difficult to draw firm conclusions. There is some evidence, however, that the program impact is higher for larger families in British Columbia.

Although the SSP supplement leads to an increase in full-time employment, it appears that recipients are taking jobs that pay relatively low wages - within $\$ 1.00$ to $\$ 3.00$ per hour above the minimum wage. This is consistent with the view that many long-term welfare recipients have low wage opportunities. Unless the SSP participants experience substantial wage growth in their three years of program eligibility, it is conceivable that many recipients will return to welfare when the supplement ends. 


\section{REFERENCES}

Bancroft, Wendy, and Vernon, Sheila Currie. 1995. The Struggle for Self-Sufficiency: Participants in the Self-Sufficiency Project Talk About Work, Welfare, and Their Futures. Vancouver: Social Research and Demonstration Corporation.

Blank, Rebecca, and Hanratty, Maria. 1993. "Responding to Need: A Comparison of Social Safety Nets in Canada and the United States." In Small Differences that Matter: Labor Markets and Income Maintenance in Canada and the United States, ed. David Card and Richard B. Freeman. Chicago: University of Chicago Press.

Courchene, Thomas J. 1994. Social Canada in the Millennium. Toronto: C. D. Howe Institute.

Friedlander, Daniel, and Burtless, Gary. 1995. Five Years After: The Long-Term Effects of Welfare-to-Work Programs. New York: Russell Sage Foundation.

Greenberg, David H.; Long, David; Meyer, Daniel; Michalopoulos, Charles; and Robins, Philip K. 1995. "Using Microsimulation to Help Design Pilot Demonstrations: An Illustration from the Canadian Self-Sufficiency Project." In Evaluation Review. 19(6):687-706.

Greenberg, David H.; Michalopoulos, Charles; Robins, Philip K.; and Wood, Robert. 1995. "Making Work Pay for Welfare Recipients." In Contemporary Economic Policy. 13(2):3952.

Greenberg, David H., and Wiseman, Michael. 1992. "What Did the OBRA Demonstrations Do?" In Evaluating Welfare and Training Programs, ed. Charles F. Manski and Irwin Garfinkel. Cambridge, Mass.: Harvard University Press.

Gueron, Judith M. 1991. "Work and Welfare: Lessons on Employment Programs." In Journal 
of Economic Perspectives. 4(1):79-98.

Gueron, Judith M., and Pauly, Edward. 1991. From Welfare to Work. New York: Russell Sage Foundation.

Hoffman, Saul D., and Seidman, Laurence S. 1990. The Earned Income Tax Credit: AntiPoverty Effectiveness and Labor Market Effects. Kalamazoo, Mich.: The W. E. Upjohn Institute for Employment Research.

Hum, Derek, and Simpson, Wayne. 1991. Income Maintenance, Work Effort, and the Canadian Mincome Experiment. Ottawa: Minister of Supply and Services Canada.

Kesselman, Jonathan R., and Riddell, Craig W. 1991. Assessment of Alternative Subsidy Treatments for the EIC Self-Sufficiency Project. Ottawa: Employment and Immigration Canada.

Lemieux, Thomas; Fortin, Bernard; and Frechette, Pierre. 1994. "The Effect of Taxes on Labor Supply in the Underground Economy. " In American Economic Review. 84(1):231254.

Lui-Gurr, Susanna; Vernon, Sheila Currie; and Mijanovich, Tod. 1994. Making Work Pay Better Than Welfare: An Early Look at the Self-Sufficiency Project. Vancouver: Social Research and Demonstration Corporation.

Mijanovich, Tod, and Long, David. 1995. Creating an Alternative to Welfare: First-Year Findings on the Implementation, Welfare Impacts, and Costs of the Self-Sufficiency Project. Vancouver: Social Research and Demonstration Corporation.

Moffitt, Robert. 1983a. "The Individual Work Incentives and Labor Market Impacts of Transfer Programs With a Work Requirement: The Static Theory." In Quarterly Review of Economics and Business. 23(1):35-45. 
Moffitt, Robert. 1983b. "An Economic Model of Welfare Stigma." In American Economic Review. 73:1023-35.

Moffitt, Robert. 1992. "Evaluation Methods for Program Entry Effects." In Evaluating Welfare and Training Programs, ed. Charles F. Manski and Irwin Garfinkel. Cambridge, Mass.: Harvard University Press.

Moffitt, Robert, and Kehrer, Kenneth C. 1981. "The Effects of Tax and Transfer Programs on Labor Supply." In Research in Labor Economics, ed. Ronald Ehrenberg. Greenwich, Conn.: JAI Press. 103-150.

Munnell, Alicia H., ed. 1986. Lessons from the Income Maintenance Experiments. Boston: Federal Reserve Bank of Boston.

National Council of Welfare. 1992. Welfare Reform. Ottawa: National Council of Welfare.

Riccio, James; Friedlander, Daniel; and Freedman, Stephen. 1994. GAIN: Benefits, Costs, and Three-Year Impacts of a Welfare-to-Work Program. New York: Manpower Demonstration Research Corporation.

Robins, Philip K. 1985. "A Comparison of the Labor Supply Findings from the Four Negative Income Tax Experiments." In Journal of Human Resources. 20:567-582.

Scholz, John Karl. 1993. "Tax Policy and the Working Poor: The Earned Income Tax Credit." In Focus. Vol. 15.

Social Research and Demonstration Corporation in cooperation with Manpower Demonstration Research Corporation. 1993. Design of the Self-Sufficiency Project. Report prepared for Employment and Immigration Canada. 
Figure 1

Monthly Income for a Single Parent with One Child in British Columbia

Under LA (with the Basic Earnings Disregard) and Under SSP, at the Minimum Wage of \$6 Per Hour

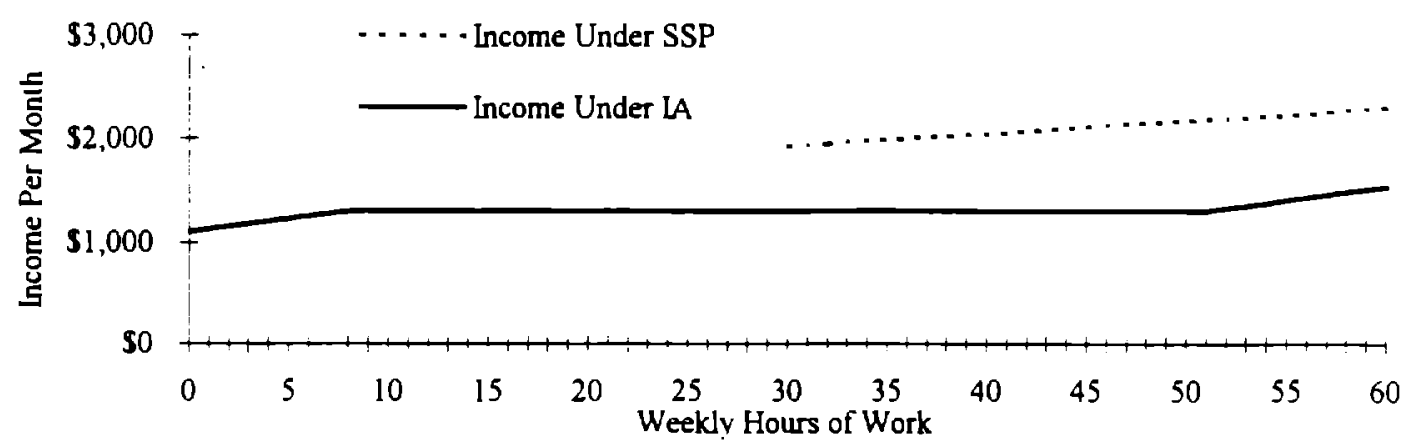

NOTE: The basic eamings distegard program allows British Columbia LA recipients to keep the first $\mathbf{\$ 2 0 0}$ of earnings per month without their LA payment being reduced.

Figure 2

Monthly Income for a Single Parent with One Child in British Columbia Under IA (with the Enhanced Earnings Disregard) and Under SSP, at the Minimum Wage of S6 Per Bour

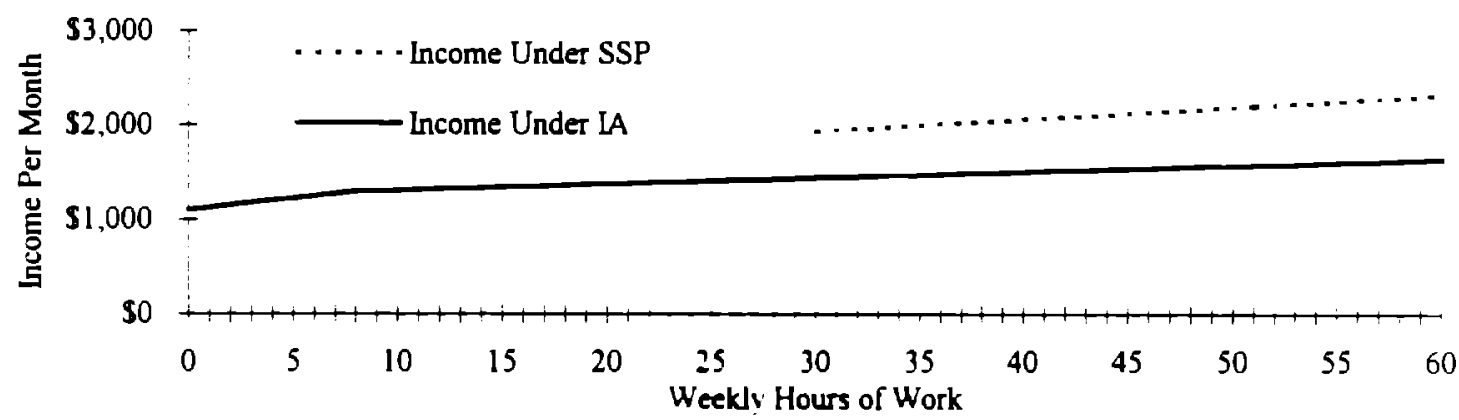

NOTE: The enhanced eamings disregard program allows Bntısh Columbia IA recipients to keep the first $\$ 200$ of earnings and 25 percent of remaining earmungs per month, without their LA payment being reduced, for up to 18 months of eamings.

Figure 3

Monthly Income for a Single Parent with One Child in New Brunswick Under IA and Under SSP, at the Minimum Wage of S5 Per Hour

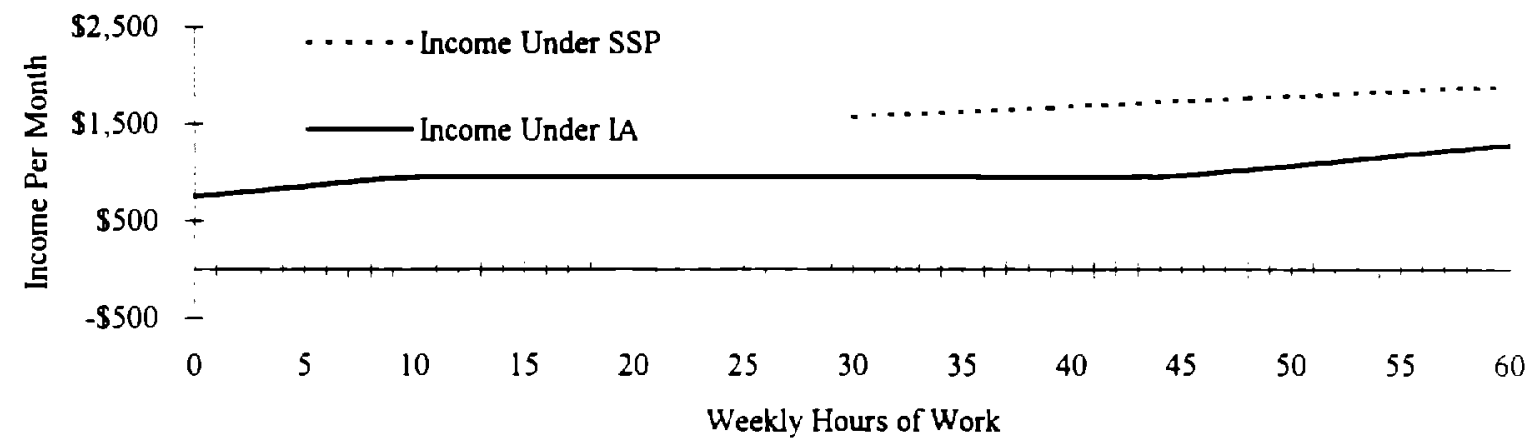


Figure 4

Percentage of Program Group Members in the 18-Month Sample Receiving SSP Supplement Payments

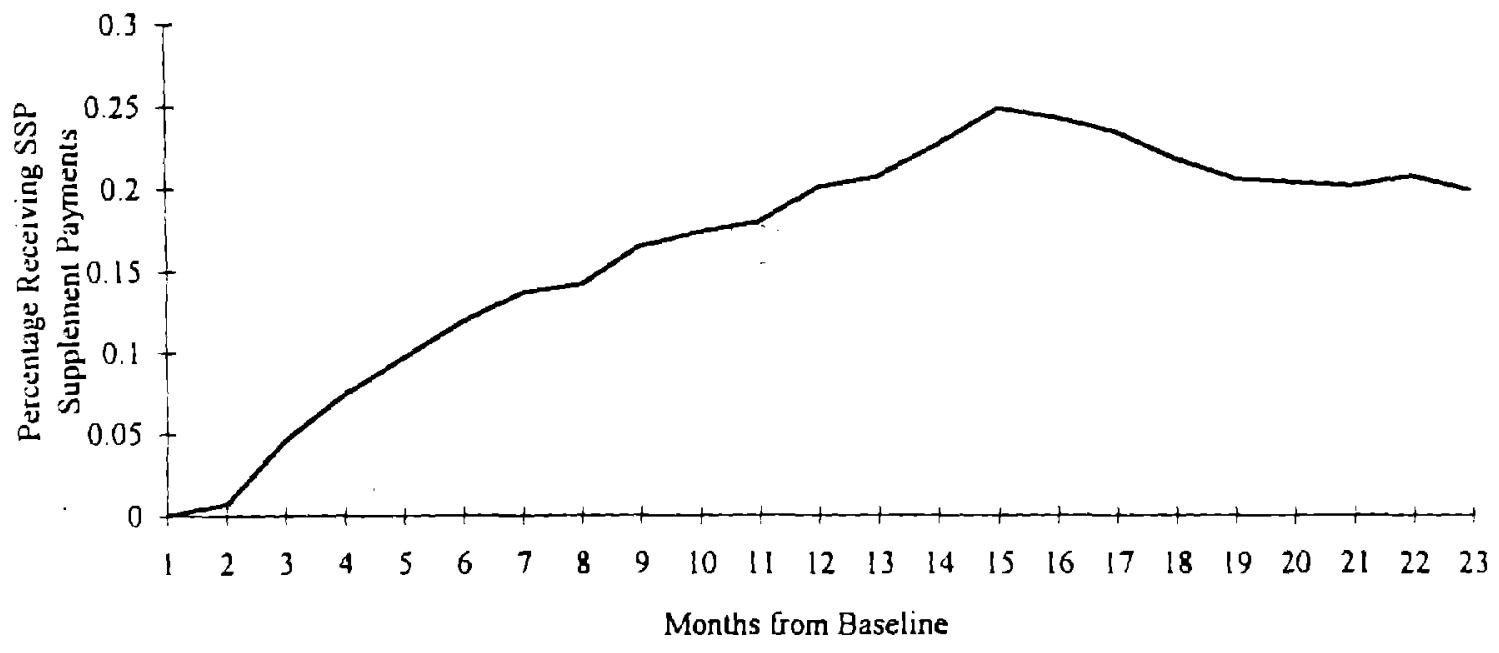




\section{Figure 5}

Average Monthly Earnings for the Full SSP 18-Month Survey Sample

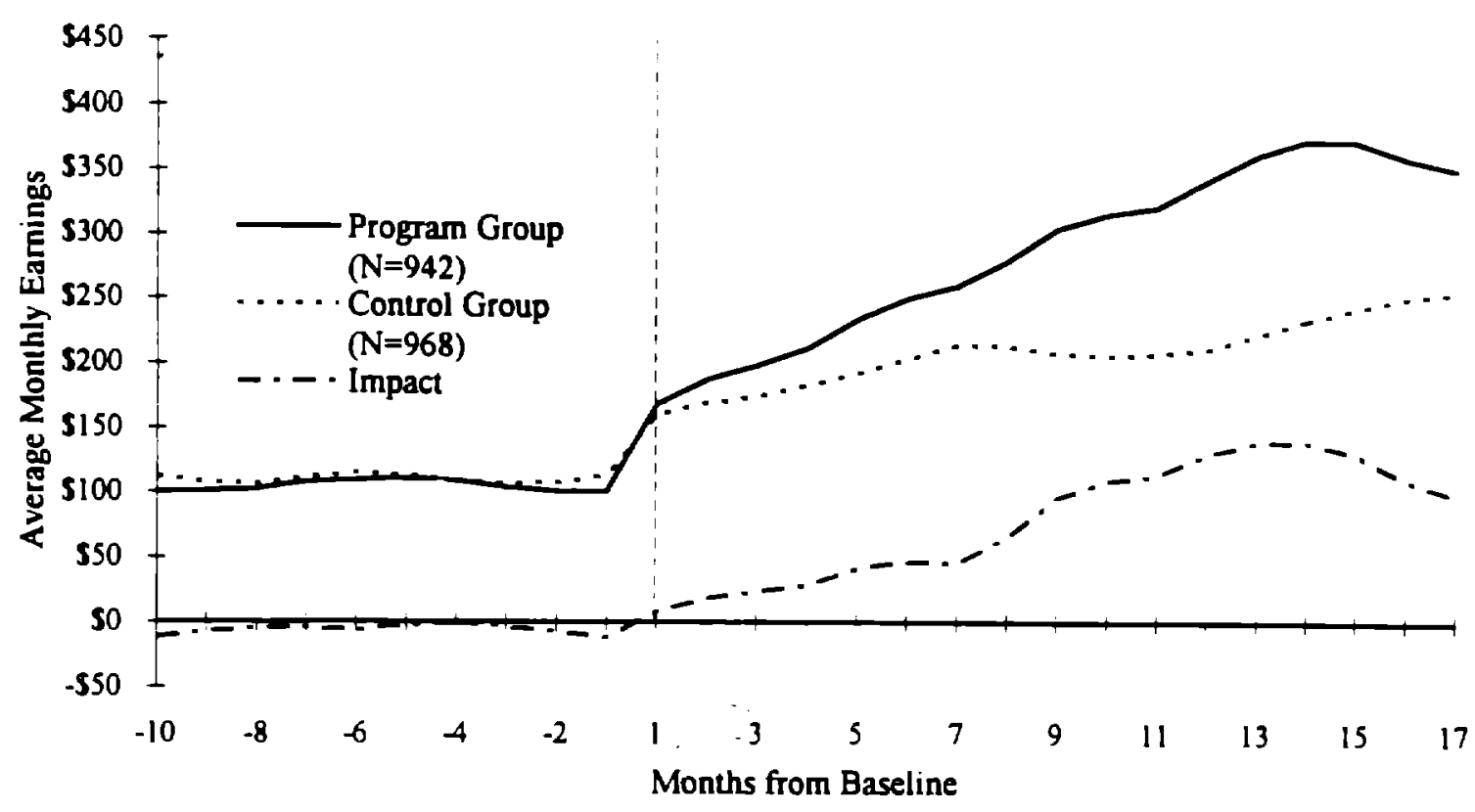

Figure 6

Average Monthly Hours of Work

for the Full SSP 18-Month Survey Sample

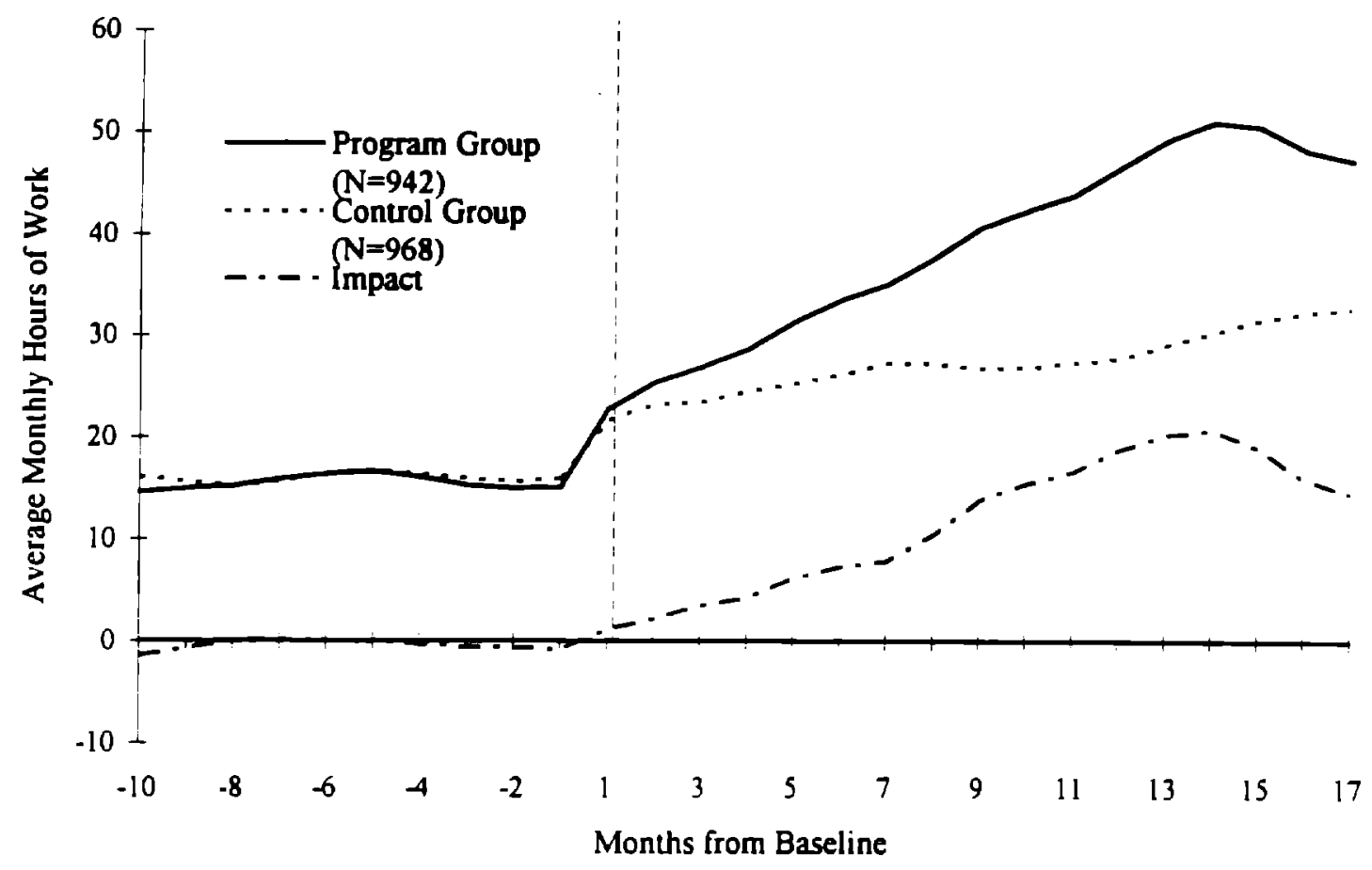


Figure 7

Monthly Employment Rates (Average Weekly Hours

Greater than 0) for the Full SSP 18-Month Sample

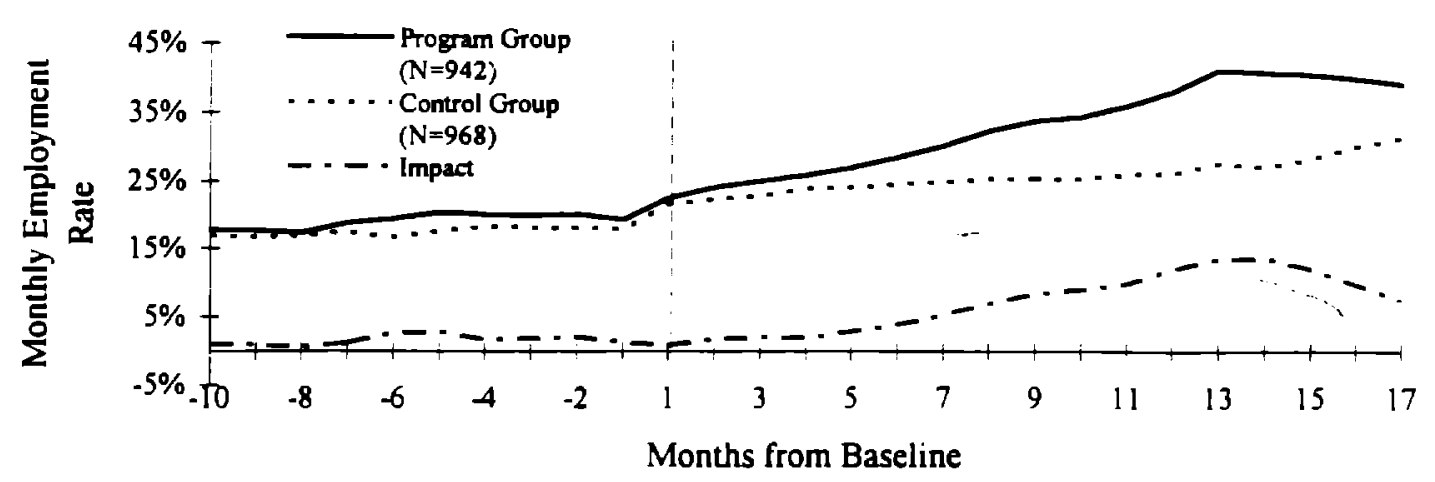

Figure 8

Monthly Full-Time Employment Rates (Average Weekly Hours

Equal to 30 and Above) for the Full SSP 18-Month Sample

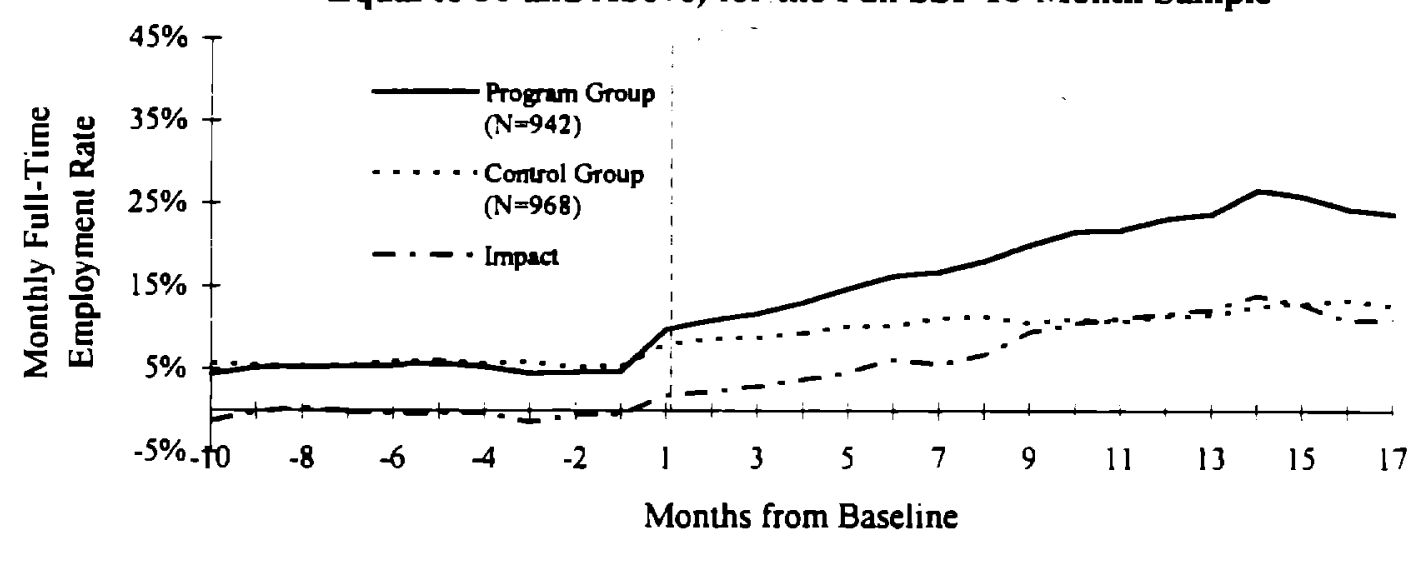

Figure 9

Monthly Part-Time Employment Rates (Average Weekly Hours

Between 1 and 30) for the Full SSP 18-Month Sample

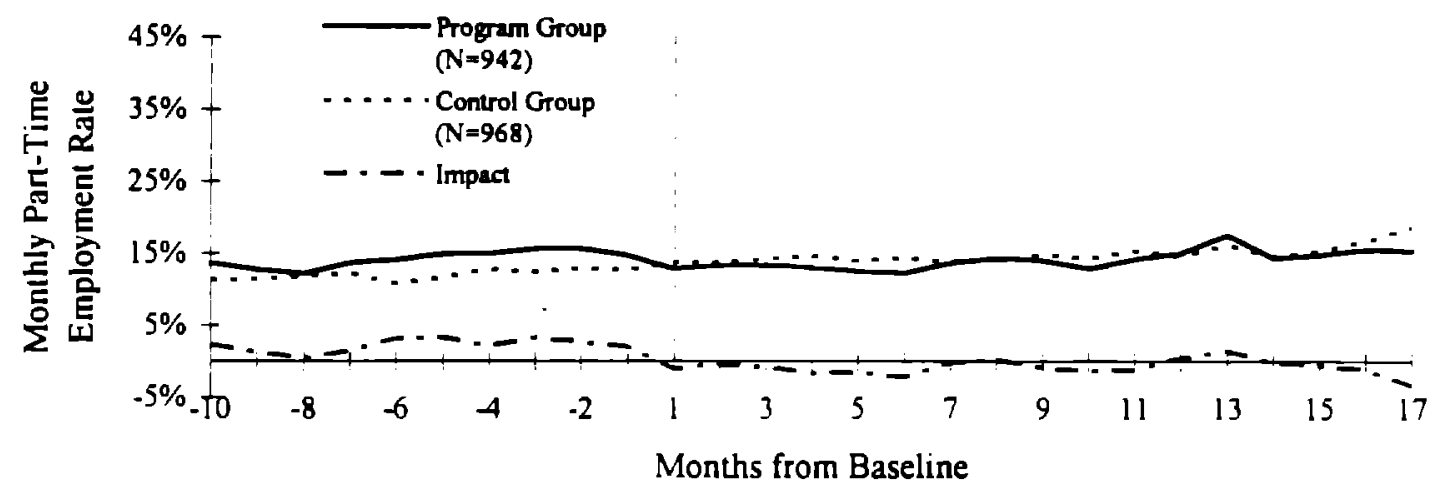


Figure 10

Average Monthly IA Payments

for the Full SSP 18-Month Sample

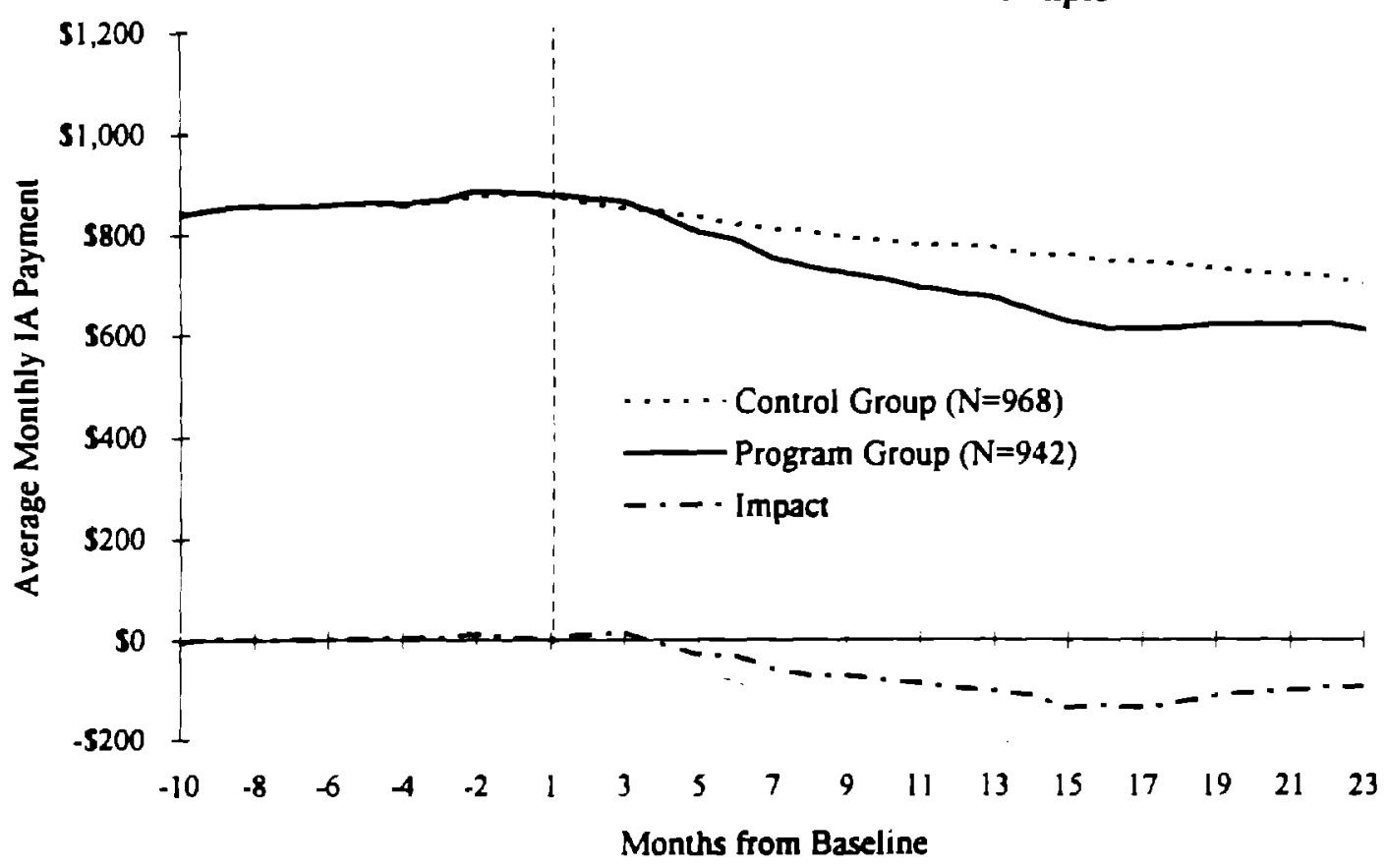

Figure 11

Percentage Off IA Among the

Full SSP 18-Month Sample

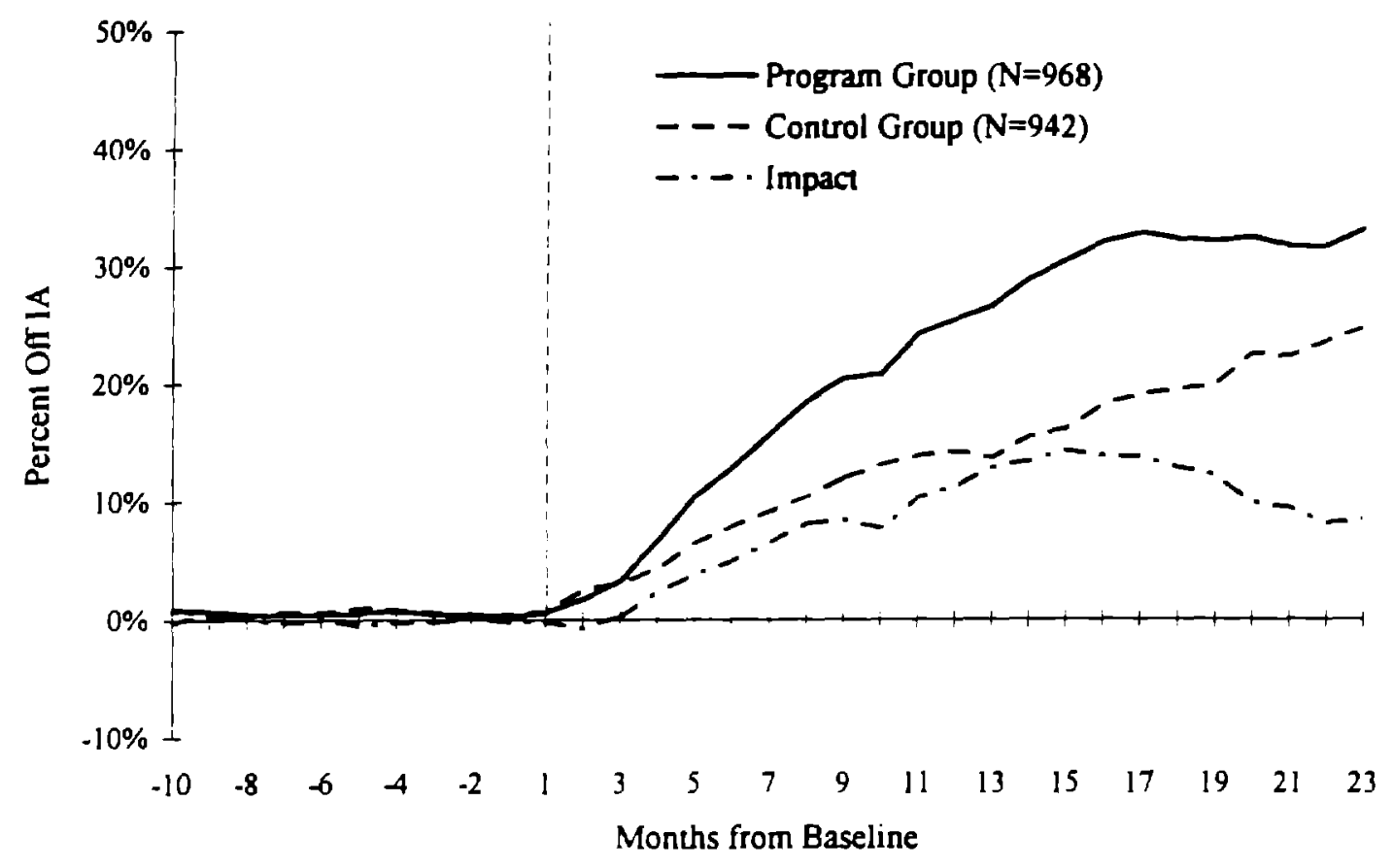


Figure 12

Average Monthly IA and SSP Payments

for the Full SSP 18-Month Sample

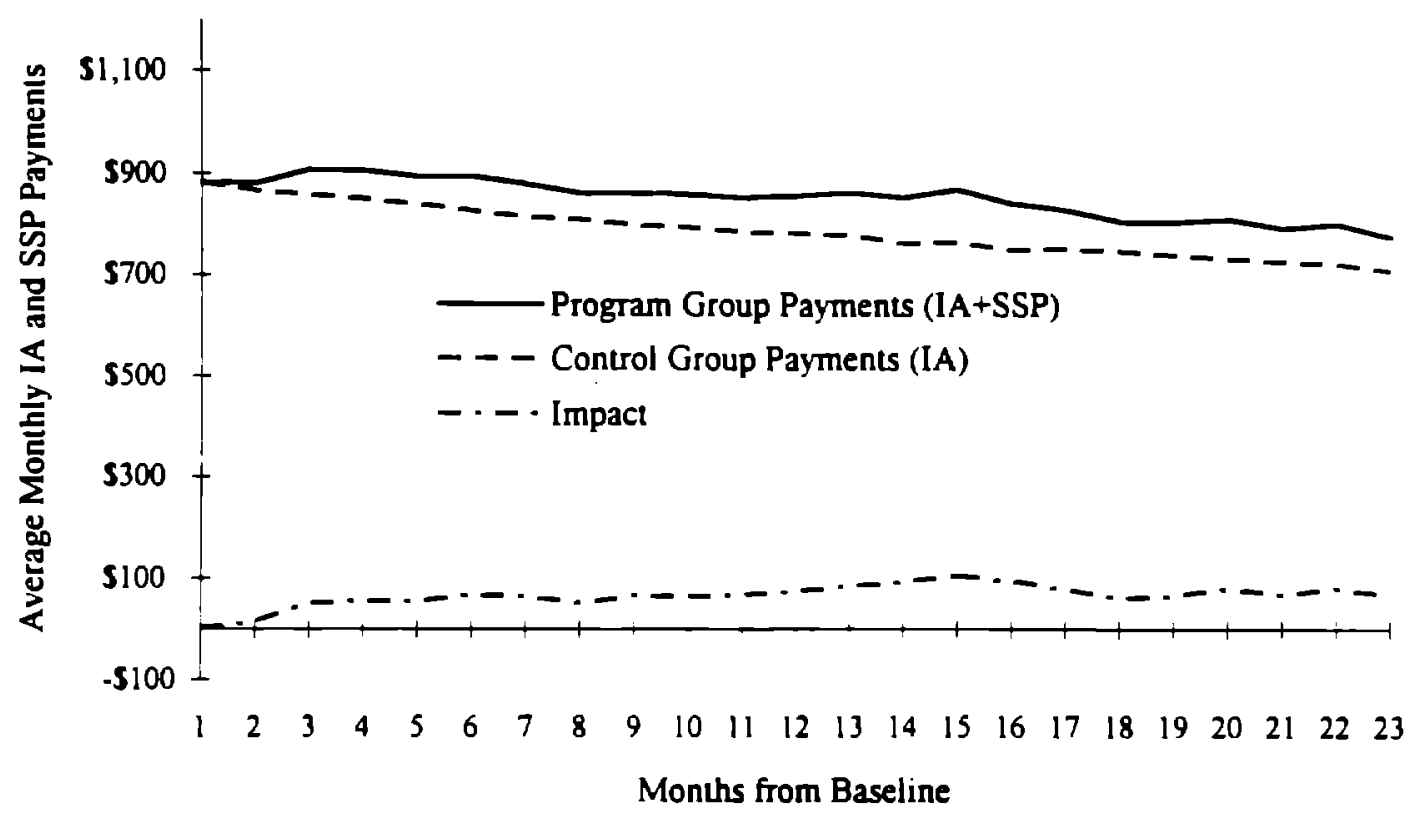

Figure 13

Percentage On IA or SSP Among the Full SSP 18-Month Sample

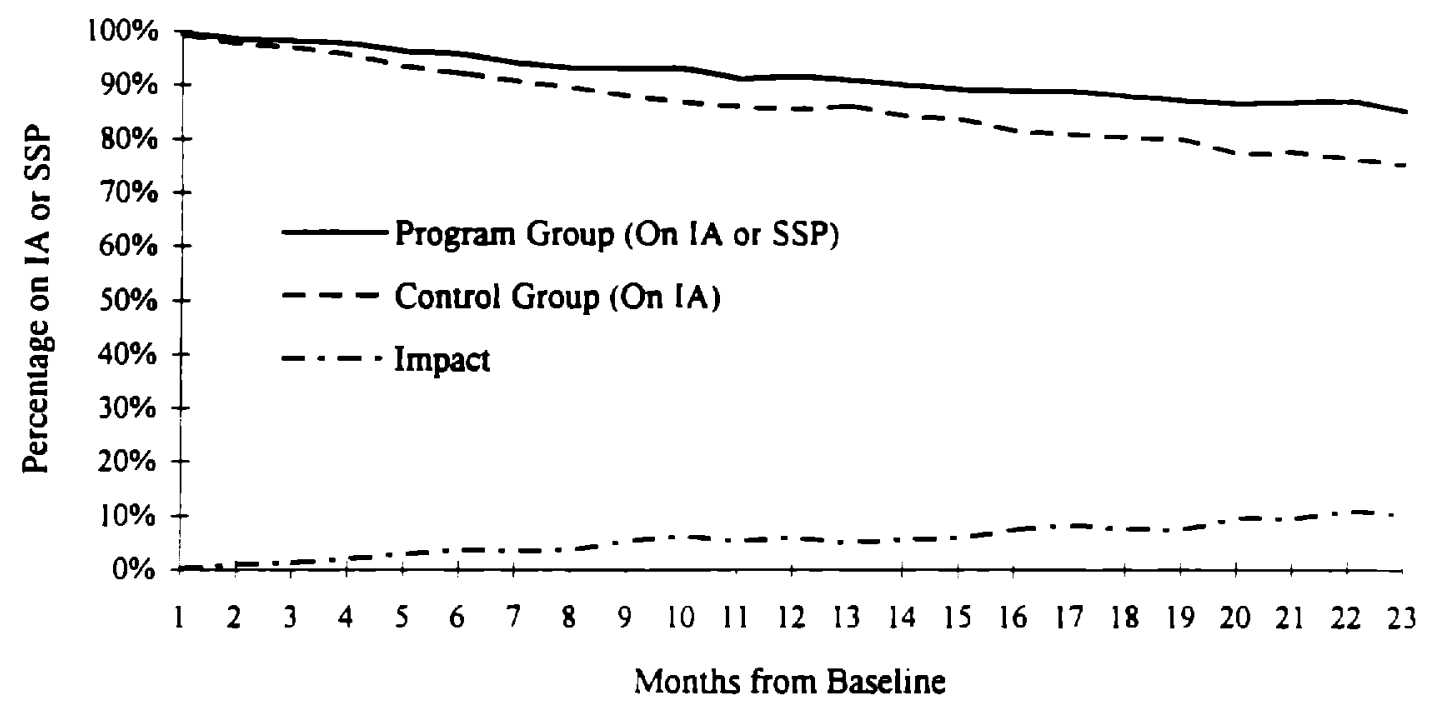


Selected Characteristics of the British Columbia and New Brunswick Labour Markets, LA Program, and SSP Earnings Supplement Program

\begin{tabular}{|c|c|c|c|}
\hline Characteristic & $\begin{array}{r}\text { British } \\
\text { Columbia } \\
\end{array}$ & $\begin{array}{r}\text { New } \\
\text { Brunstrick } \\
\end{array}$ & Canada \\
\hline \multicolumn{4}{|l|}{ Basic labor market } \\
\hline Adult population, 1994 (thousands) & 2,869 & 594 & 22,717 \\
\hline \multicolumn{4}{|l|}{ Employment/population rate } \\
\hline 1992 & 59.4 & 51.5 & 58.1 \\
\hline 1993 & 59.9 & 51.8 & 58.2 \\
\hline 1994 & 60.4 & 51.7 & 58.5 \\
\hline \multicolumn{4}{|l|}{ Unemployment rate } \\
\hline 1992 & 10.4 & 12.8 & 11.3 \\
\hline 1993 & 9.7 & 12.6 & 11.2 \\
\hline 1994 & 9.4 & 12.4 & 10.4 \\
\hline \multicolumn{4}{|l|}{ Proportion of families below low-income cutoff } \\
\hline 1992 & 13.5 & 11.5 & 13.3 \\
\hline 1993 & 13.9 & 11.5 & 14.5 \\
\hline Minimum wage (1994, S/hour) & 6.00 & 5.00 & - \\
\hline $\begin{array}{l}\text { Average monthly earaings of full-time } \\
\text { female workers (\$) }\end{array}$ & 2,375 & 1,892 & 2,367 \\
\hline \multicolumn{4}{|l|}{ A program } \\
\hline $\begin{array}{l}\text { Average statutory LA } \\
\text { grant for single parents (\$) }\end{array}$ & 1,079 & 733 & - \\
\hline \multicolumn{4}{|l|}{ SSP Earnings Supplement Program } \\
\hline SSP break-even (\$/month) ${ }^{c}$ & 3,083 & 2,500 & - \\
\hline $\begin{array}{l}\text { Minimum monthly eamings for } \\
\text { SSP eligibility }\end{array}$ & 780 & 650 & -- \\
\hline $\begin{array}{l}\text { Monthly earnings and SSP supplement } \\
\text { assuming minimum wage and } 30 \text { hours/week }\end{array}$ & 1,932 & 1,575 & - \\
\hline $\begin{array}{l}\text { Ratio: SSP income (earnings plus supplement)//A } \\
\text { grant (\%) (row } 10 / \text { row } 7 \text { ) }\end{array}$ & 179.1 & 214.9 & - \\
\hline
\end{tabular}

SOURCES: Basic labor market data are from Perspectives on Labour and Income, Summer 1994 and Summer 1995 editions. Employment/population rates are computed from population and employment statistics. Average monthly earnings of female workers is constructed by dividing annual earnings for full-time full-year female workers in 1993 by 12 .

IA program data are from the British Columbia Ministry of Social Services and the Department of Human Resources Development - New Brunswick. The rate for New Brunswick is for the Upgrading, Training, and Placement program.

NOTES: 'Low-income cutoffs (LICOs) are earnings levels determined and utilized by Statistics Canada to identify low-income family units. LICOs are estimated as the income level at which a family spends 20 percentage points more than the Canadian average on food, sheiter, and clothing

${ }^{b}$ Average of rates for single parents with one and two children.

cThe level of monthly earnings beyond which the SSP supplement is 0 .

dSum of monthly eamings assuming 30 hours of work per week at the minimum wage. plus SSP subsidy equal to half the difference between the target Threalr_aven isminne 
Table 2: Meana of Selected Characteristics: Overall, By Province, and By Program Group

\begin{tabular}{|c|c|c|c|c|c|}
\hline $\begin{array}{l}\text { Overall } \\
\text { (1) }\end{array}$ & $\begin{array}{l}\text { 8c only } \\
\text { (2) }\end{array}$ & $\begin{array}{l}\text { NB onty } \\
\text { (3) }\end{array}$ & $\begin{array}{l}\text { Controls } \\
\text { Only } \\
(4)\end{array}$ & $\begin{array}{l}\text { Prograns } \\
\text { only } \\
\text { (5) }\end{array}$ & $\begin{array}{l}\text { t-statistic } \\
\text { for difference: } \\
\text { Prograng-Controls } \\
\begin{array}{l}\text { (6) }\end{array}\end{array}$ \\
\hline
\end{tabular}

Personal Characteristics:

\begin{tabular}{|c|c|c|c|c|c|c|c|}
\hline 1. & Percent Female & $\begin{array}{l}95.6 \\
(0.5)\end{array}$ & $\begin{array}{l}94.9 \\
(0.6)\end{array}$ & $\begin{array}{l}96.9 \\
(0.7)\end{array}$ & $\begin{array}{l}95.6 \\
(0.7)\end{array}$ & $\begin{array}{l}95.6 \\
(0.7)\end{array}$ & 0.0 \\
\hline 2. & Average Age & $\begin{array}{l}32.4 \\
(0.2)\end{array}$ & $\begin{array}{l}32.6 \\
(0.2)\end{array}$ & $\begin{array}{l}31.9 \\
(0.4)\end{array}$ & $\begin{array}{l}32.4 \\
(0.3)\end{array}$ & $\begin{array}{l}32.3 \\
(0.3)\end{array}$ & -0.2 \\
\hline 3. & $\begin{array}{l}\text { Percent Under } \\
\text { Age } 25\end{array}$ & $\begin{array}{l}20.9 \\
(0.9)\end{array}$ & $\begin{array}{l}19.4 \\
(1.1)\end{array}$ & $\begin{array}{l}23.9 \\
(1.7)\end{array}$ & $\begin{array}{l}21.7 \\
(1.4)\end{array}$ & $\begin{array}{l}20.1 \\
(1.3)\end{array}$ & -0.8 \\
\hline 4. & $\begin{array}{l}\text { Percent Less Then } \\
\text { High School }\end{array}$ & $\begin{array}{l}54.0 \\
(1.2)\end{array}$ & $\begin{array}{l}53.1 \\
(1.4)\end{array}$ & $\begin{array}{l}55.8 \\
(2.0)\end{array}$ & $\begin{array}{l}55.9 \\
(1.6)\end{array}$ & $\begin{array}{l}52.1 \\
(1.7)\end{array}$ & -1.6 \\
\hline 5. & $\begin{array}{l}\text { Percent Finished } \\
\text { High School, No } \\
\text { Post-Secondiry }\end{array}$ & $\begin{array}{l}34.4 \\
(1.1)\end{array}$ & $\begin{array}{l}34.5 \\
(1.6)\end{array}$ & $\begin{array}{l}34.0 \\
(1.9)\end{array}$ & $\begin{array}{l}32.1 \\
(1.5)\end{array}$ & $\begin{array}{l}36.7 \\
(1.6)\end{array}$ & 2.1 \\
\hline 6. & $\begin{array}{l}\text { Percent with Some } \\
\text { Post-Secondary }\end{array}$ & $\begin{array}{l}11.6 \\
(0.7)\end{array}$ & $\begin{array}{l}12.4 \\
(0.9)\end{array}$ & $\begin{array}{l}10.2 \\
(1.2)\end{array}$ & $\begin{array}{l}12.0 \\
(1.1)\end{array}$ & $\begin{array}{l}11.2 \\
(1.0)\end{array}$ & -0.6 \\
\hline 7. & $\begin{array}{l}\text { Percent First- } \\
\text { Nation Ancestory }\end{array}$ & $\begin{array}{l}9.9 \\
(0.7)\end{array}$ & $\begin{array}{l}12.0 \\
(0.9)\end{array}$ & $\begin{array}{l}5.6 \\
(0.9)\end{array}$ & $\begin{array}{l}10.5 \\
(1.0)\end{array}$ & $\begin{array}{l}9.2 \\
(1.0)\end{array}$ & -0.9 \\
\hline 8. & $\begin{array}{l}\text { Percent Canedian } \\
\text { Ancestory }\end{array}$ & $\begin{array}{l}45.7 \\
(1.2)\end{array}$ & $\begin{array}{l}40.1 \\
(1.4)\end{array}$ & $\begin{array}{l}56.8 \\
(2.0)\end{array}$ & $\begin{array}{l}43.9 \\
(1.6)\end{array}$ & $\begin{array}{l}47.5 \\
(1.7)\end{array}$ & 1.6 \\
\hline 9. & $\begin{array}{l}\text { Percent Born in } \\
\text { Canada }\end{array}$ & $\begin{array}{l}83.7 \\
(0.9)\end{array}$ & $\begin{array}{l}76.7 \\
(1.2)\end{array}$ & $\begin{array}{l}97.4 \\
(0.6)\end{array}$ & $\begin{array}{l}82.5 \\
(1.2)\end{array}$ & $\begin{array}{l}84.9 \\
(1.2)\end{array}$ & 1.4 \\
\hline 10. & $\begin{array}{l}\text { Percent French- } \\
\text { Speaking }\end{array}$ & $\begin{array}{l}10.2 \\
(0.7)\end{array}$ & $\begin{array}{l}3.8 \\
(0.5)\end{array}$ & $\begin{array}{l}22.9 \\
(1.7)\end{array}$ & $\begin{array}{l}10.8 \\
(1.0)\end{array}$ & $\begin{array}{l}9.5 \\
(1.0)\end{array}$ & -0.9 \\
\hline 11. & $\begin{array}{l}\text { - Percent Speaking } \\
\text { Other Language }\end{array}$ & $\begin{array}{l}16.7 \\
(0.8)\end{array}$ & $\begin{array}{l}21.6 \\
(1.2)\end{array}$ & $\begin{array}{l}1.1 \\
(0.4)\end{array}$ & $\begin{array}{l}15.7 \\
(1.2)\end{array}$ & $\begin{array}{l}13.7 \\
(1.1)\end{array}$ & -1.2 \\
\hline
\end{tabular}

Fanily Background:
(1.4)

59.8

(1.4)

56.9

76.5

(1.7)

79.5

(1.6)

65.6

(1.9)

20.9

(1.2)
28.1

(1.8)
12. Pct. Mother Didn't 65.6 Finish High School $(1.1)$

\section{7}

13. Pct. Father Didn't 66.4 Finish High School (1.1)

14. Pct. Hed Both Parents in Hom

\section{8}

(1.1)

15. Pct. Fanily on IA as Child

\section{3}

$$
\text { (1.0) }
$$

66.4

(1.5)

66.1

(1.6)

58.3

(1.6)

25.0

(1.4)
64.3

(1.6)

66.8

(1.6)

61.4

(1.6)

21.5

(1.4)
$-0.9$

0.4

1.3

$-1.8$

Family structure:

16. Total Number of children

1.5

1.5

1.4

(0.0)

1.5

(0.0)

1.5

(0.0)

\section{7}

(0.0)

0.7

(0.0)

(0.0) Under Age 6

(0.0)

(0.0)
.0

0.2

.8

1.6

.1

.6

.9

.6

.4

.9

.2

Note: Standard errors of means in parentheses. All characteristics are measured as of Basel ine Interview unless otherwise indicated. Entry in colum (6) is the t-statistic for a test that the mean is the sane for the control group and program group.

Table cont inves.... 
Table 2, cont inued

\begin{tabular}{|c|c|c|c|c|c|c|}
\hline & $\begin{array}{l}\text { Overall } \\
\text { (1) }\end{array}$ & $\underset{(2)}{B C}$ Only & $\begin{array}{l}\text { NB Only } \\
\text { (3) }\end{array}$ & $\begin{array}{l}\text { Controls } \\
\text { Only } \\
(4)\end{array}$ & $\begin{array}{l}\text { Programs } \\
\text { Only } \\
\text { (5) }\end{array}$ & $\begin{array}{c}\text { t-statistic } \\
\text { for difference: } \\
\text { Prograns-Controls } \\
\text { (6) }\end{array}$ \\
\hline $\begin{array}{l}\text { 18. Percent tho Need } \\
\text { Some Childcare }\end{array}$ & $\begin{array}{l}95.1 \\
(0.5)\end{array}$ & $\begin{array}{l}96.2 \\
(0.6)\end{array}$ & $\begin{array}{l}92.9 \\
(1.0)\end{array}$ & $\begin{array}{l}95.4 \\
(0.7)\end{array}$ & $\begin{array}{l}94.7 \\
(0.7)\end{array}$ & -0.6 \\
\hline $\begin{array}{l}\text { 19. Percent Divorced, } \\
\text { Seporated, Uidowed }\end{array}$ & $\begin{array}{l}53.6 \\
(1.2)\end{array}$ & $\begin{array}{l}54.4 \\
(1.4)\end{array}$ & $\begin{array}{l}51.9 \\
(2.0)\end{array}$ & $\begin{array}{l}53.4 \\
(1.6)\end{array}$ & $\begin{array}{l}53.8 \\
(1.7)\end{array}$ & 0.2 \\
\hline $\begin{array}{l}\text { 20. Percent Never } \\
\text { Married }\end{array}$ & $\begin{array}{l}44.6 \\
(1.2)\end{array}$ & $\begin{array}{l}43.9 \\
(1.4)\end{array}$ & $\begin{array}{l}46.1 \\
(2.0)\end{array}$ & $\begin{array}{l}44.7 \\
(1.6)\end{array}$ & $\begin{array}{l}44.6 \\
(1.6)\end{array}$ & -0.1 \\
\hline 21. Percent Oun Howe & $\begin{array}{l}6.3 \\
(0.6)\end{array}$ & $\begin{array}{l}3.8 \\
(0.6)\end{array}$ & $\begin{array}{l}11.1 \\
(1.3)\end{array}$ & $\begin{array}{l}7.1 \\
(0.8)\end{array}$ & $\begin{array}{l}5.5 \\
(0.8)\end{array}$ & -1.4 \\
\hline $\begin{array}{l}\text { 22. Percent Receiving } \\
\text { Housing Subsidy }\end{array}$ & $\begin{array}{l}22.6 \\
(1.0)\end{array}$ & $\begin{array}{l}18.6 \\
(1.1)\end{array}$ & $\begin{array}{l}30.6 \\
(1.8)\end{array}$ & $\begin{array}{l}21.5 \\
(1.3)\end{array}$ & $\begin{array}{l}23.8 \\
(1.4)\end{array}$ & 1.2 \\
\hline \multicolumn{7}{|l|}{ IA History: } \\
\hline $\begin{array}{l}\text { 23. Number of Months } \\
\text { on IA Last } 3 \text { Yrs. }\end{array}$ & $\begin{array}{l}29.7 \\
(0.2)\end{array}$ & $\begin{array}{l}29.0 \\
(0.2)\end{array}$ & $\begin{array}{l}31.1 \\
(0.3)\end{array}$ & $\begin{array}{l}29.4 \\
(0.3)\end{array}$ & $\begin{array}{l}30.0 \\
(0.3)\end{array}$ & 1.4 \\
\hline $\begin{array}{l}\text { 24. Percent Current } \\
\text { IA Spell }>2 \text { Yrs. }\end{array}$ & $\begin{array}{l}60.5 \\
(1.1)\end{array}$ & $\begin{array}{l}57.4 \\
(1.4)\end{array}$ & $\begin{array}{l}66.8 \\
(1.9)\end{array}$ & $\begin{array}{l}58.8 \\
(1.6)\end{array}$ & $\begin{array}{l}62.3 \\
(1.6)\end{array}$ & 1.6 \\
\hline $\begin{array}{l}\text { 25. IA Received Last } \\
\text { Month (\$) }\end{array}$ & $\begin{array}{c}886.4 \\
(7.1)\end{array}$ & $\begin{array}{r}1004.0 \\
(8.0)\end{array}$ & $\begin{array}{c}655.3 \\
(7.9)\end{array}$ & $\begin{array}{l}886.3 \\
(10.0)\end{array}$ & $\begin{array}{c}886.4 \\
(9.8)\end{array}$ & 0.0 \\
\hline \multicolumn{7}{|l|}{ Hork History: } \\
\hline $\begin{array}{l}\text { 26. Percent Ever } \\
\text { Had Paid Job }\end{array}$ & $\begin{array}{l}94.8 \\
(0.5)\end{array}$ & $\begin{array}{l}94.7 \\
(0.6)\end{array}$ & $\begin{array}{l}95.2 \\
(0.9)\end{array}$ & $\begin{array}{l}94.7 \\
(0.7)\end{array}$ & $\begin{array}{l}95.0 \\
(0.7)\end{array}$ & 0.2 \\
\hline $\begin{array}{l}\text { 27. Number Years of } \\
\text { Employment }\end{array}$ & $\begin{array}{l}7.4 \\
(0.2)\end{array}$ & $\begin{array}{l}8.0 \\
(0.2)\end{array}$ & $\begin{array}{l}6.4 \\
(0.2)\end{array}$ & $\begin{array}{l}7.6 \\
(0.2)\end{array}$ & $\begin{array}{l}7.3 \\
(0.2)\end{array}$ & -0.8 \\
\hline $\begin{array}{l}\text { 28. Number of Months } \\
\text { Horked Last } 10 \text { Mo. }\end{array}$ & $\begin{array}{l}1.8 \\
(0.1)\end{array}$ & $\begin{array}{l}1.6 \\
(0.1)\end{array}$ & $\begin{array}{c}2.2 \\
(0.1)\end{array}$ & $\begin{array}{l}1.7 \\
(0.1)\end{array}$ & $\begin{array}{l}1.9 \\
(0.1)\end{array}$ & 1.4 \\
\hline $\begin{array}{l}\text { 29. Avg. Earnings per } \\
\text { Month Last } 10 \text { Mo. }\end{array}$ & $\begin{array}{c}107.2 \\
(6.1)\end{array}$ & $\begin{array}{c}106.5 \\
(8.0)\end{array}$ & $\begin{array}{c}108.5 \\
(8.9)\end{array}$ & $\begin{array}{c}106.8 \\
(9.0)\end{array}$ & $\begin{array}{c}107.6 \\
(8.1)\end{array}$ & 0.1 \\
\hline $\begin{array}{l}\text { 30. Percent Horked } \\
\text { Last Month }\end{array}$ & $\begin{array}{l}18.3 \\
(0.9)\end{array}$ & $\begin{array}{l}16.8 \\
(1.1)\end{array}$ & $\begin{array}{l}21.5 \\
(1.6)\end{array}$ & $\begin{array}{l}17.4 \\
(1.2)\end{array}$ & $\begin{array}{l}19.3 \\
(1.3)\end{array}$ & 1.1 \\
\hline \multicolumn{7}{|l|}{ Location: } \\
\hline $\begin{array}{l}\text { 31. Percent Urban } \\
\text { Locetion }\end{array}$ & $\begin{array}{l}90.0 \\
(0.7)\end{array}$ & $\begin{array}{l}94.3 \\
(0.7)\end{array}$ & $\begin{array}{l}81.6 \\
(1.6)\end{array}$ & $\begin{array}{l}90.9 \\
(0.9)\end{array}$ & $\begin{array}{l}89.1 \\
(1.0)\end{array}$ & -1.2 \\
\hline 32. Percent in $\mathrm{BC}$ & $\begin{array}{l}66.3 \\
(1.1)\end{array}$ & $\begin{array}{l}100.0 \\
(0.0)\end{array}$ & $\begin{array}{l}0.0 \\
(0.0)\end{array}$ & $\begin{array}{l}66.4 \\
(1.5)\end{array}$ & $\begin{array}{l}66.3 \\
(1.6)\end{array}$ & -0.0 \\
\hline
\end{tabular}

Note: Standerd errors of means in parentheses. All characteristics are measured as of Baseline Interview unless otherwise indicated. Entry in colum (6) is the t-statistic for a test that the mean is the sam for the control group and program group.

ancludes individuals tho report that parent did not finish high school as well as those whose parental education data are missing. 
Table 3

Quarterly Outcomes and Program Impacts of SSP for the 18-Month Survey Sample

\begin{tabular}{|c|c|c|c|c|}
\hline $\begin{array}{l}\text { Outcome Measure } \\
\text { and Time Period }\end{array}$ & $\begin{array}{r}\text { Program } \\
\text { Group } \\
\end{array}$ & $\begin{array}{r}\text { Control } \\
\text { Group } \\
\end{array}$ & $\begin{array}{r}\text { Unadjusted } \\
\text { Impact } \\
\end{array}$ & $\begin{array}{r}\text { Adjusted } \\
\text { Impact } \\
\end{array}$ \\
\hline \multicolumn{5}{|c|}{ A. Average percentage who work each month } \\
\hline Quarter -1 & $\begin{array}{l}19.8 \\
(1.2)\end{array}$ & $\begin{array}{l}18.0 \\
(1.2)\end{array}$ & $\begin{array}{r}1.8 \\
(1.7)\end{array}$ & -- \\
\hline Quarter l & $\begin{array}{r}23.9 \\
(1.3)\end{array}$ & $\begin{array}{r}22.3 \\
(1.3)\end{array}$ & $\begin{array}{r}1.5 \\
(1.9)\end{array}$ & $\begin{array}{r}0.2 \\
(1.3)\end{array}$ \\
\hline Quarter 2 & $\begin{array}{l}27.1 \\
(1.4)\end{array}$ & $\begin{array}{r}24.2 \\
(1.3)\end{array}$ & $\begin{array}{r}2.9 \\
(1.9)\end{array}$ & $\begin{array}{r}1.7 \\
(1.6)\end{array}$ \\
\hline Quarter 3 & $\begin{array}{l}32.2 \\
(1.5)\end{array}$ & $\begin{array}{l}25.3 \\
(1.4)\end{array}$ & $\begin{array}{l}6.9 * \\
(2.0)\end{array}$ & $\begin{array}{l}5.9 * \\
(1.7)\end{array}$ \\
\hline Quarter 4 & $\begin{array}{l}36.1 \\
(1.5)\end{array}$ & $\begin{array}{l}25.8 \\
(1.4)\end{array}$ & $\begin{array}{l}10.3 * \\
(2.0)\end{array}$ & $\begin{array}{l}9.3 * \\
(1.8)\end{array}$ \\
\hline Quarter 5 & $\begin{array}{l}40.8 \\
(1.5)\end{array}$ & $\begin{array}{l}27.7 \\
(1.4)\end{array}$ & $\begin{array}{l}13.1 * \\
(2.1)\end{array}$ & $\begin{array}{l}12.2 * \\
(1.9)\end{array}$ \\
\hline Quarter 6 & $\begin{array}{l}39.3 \\
(1.5)\end{array}$ & $\begin{array}{r}30.6 \\
(1.4)\end{array}$ & $\begin{array}{l}8.7 \text { * } \\
(2.1)\end{array}$ & $\begin{array}{l}7.7^{*} \\
(1.9)^{4}\end{array}$ \\
\hline \multicolumn{5}{|c|}{ B. Average monthly earnings (\$) } \\
\hline Quarter -1 & $\begin{array}{r}102.7 \\
(8.3)\end{array}$ & $\begin{array}{r}110.0 \\
(9.7)\end{array}$ & $\begin{array}{r}-7.3 \\
(12.8)\end{array}$ & -- \\
\hline Quarter 1 & $\begin{array}{r}186.3 \\
(1+.3)\end{array}$ & $\begin{array}{l}169.2 \\
(14.0)\end{array}$ & $\begin{array}{r}17.1 \\
(20.0)\end{array}$ & $\begin{array}{r}23.3 \\
(16.8)\end{array}$ \\
\hline Quarter 2 & $\begin{array}{r}233.7 \\
(15.7)\end{array}$ & $\begin{array}{r}194.5 \\
(15.5)\end{array}$ & $\begin{array}{r}39.2 \\
(22.1)\end{array}$ & $\begin{array}{l}+3.4^{*} \\
(20.1)\end{array}$ \\
\hline Quarter 3 & $\begin{array}{l}28+.0 \\
(16.9)\end{array}$ & $\begin{array}{l}214.1 \\
(16.5)\end{array}$ & $\begin{array}{l}69.9^{*} \\
(23.6)\end{array}$ & $\begin{array}{l}74.00^{*} \\
(21.9)\end{array}$ \\
\hline Quarter 4 & $\begin{array}{r}329.5 \\
(17.9)\end{array}$ & $\begin{array}{l}210.8 \\
(16.1)\end{array}$ & $\begin{array}{l}118.7^{*} \\
(24.1)\end{array}$ & $\begin{array}{l}120.6^{*} \\
(22.4)\end{array}$ \\
\hline Quarter 5 & $\begin{array}{r}372.6 \\
(18.8)\end{array}$ & $\begin{array}{l}235.5 \\
(17.0)\end{array}$ & $\begin{array}{l}137.0^{*} \\
(25.4)\end{array}$ & $\begin{array}{l}137.3 * \\
(23.7)\end{array}$ \\
\hline Quarter 6 & $\begin{array}{l}359.0 \\
(19.5)\end{array}$ & $\begin{array}{l}254.6 \\
(17.4)\end{array}$ & $\begin{array}{l}104.4 * \\
(26.1)\end{array}$ & $\begin{array}{l}105.3^{*} \\
(24.6)\end{array}$ \\
\hline
\end{tabular}


Table 3 (continued)

\begin{tabular}{|c|c|c|c|c|}
\hline $\begin{array}{l}\text { Outcome Measure } \\
\text { and Time Period }\end{array}$ & $\begin{array}{r}\text { Program } \\
\text { Group } \\
\end{array}$ & $\begin{array}{r}\text { Control } \\
\text { Group } \\
\end{array}$ & $\begin{array}{r}\text { Unadjusted } \\
\text { Impact } \\
\end{array}$ & $\begin{array}{r}\text { Adjusted } \\
\text { Impact } \\
\end{array}$ \\
\hline \multicolumn{5}{|c|}{ C. Average monthly hours of work } \\
\hline Quarter -1 & $\begin{array}{r}15.1 \\
(1.2)\end{array}$ & $\begin{array}{r}15.8 \\
(1.3)\end{array}$ & $\begin{array}{r}-0.7 \\
(1.7)\end{array}$ & -- \\
\hline Quarter 1 & $\begin{array}{l}25.0 \\
(1.7)\end{array}$ & $\begin{array}{l}22.8 \\
(1.6)\end{array}$ & $\begin{array}{r}2.2 \\
(2.4)\end{array}$ & $\begin{array}{r}2.9 \\
(1.9)\end{array}$ \\
\hline Quarter 2 & $\begin{array}{l}31.2 \\
(1.9)\end{array}$ & $\begin{array}{l}25.4 \\
(1.7)\end{array}$ & $\begin{array}{l}5.9^{*} \\
(2.6)\end{array}$ & $\begin{array}{r}6.3 \\
(2.3)\end{array}$ \\
\hline Quarter 3 & $\begin{array}{l}37.9 \\
(2.0)\end{array}$ & $\begin{array}{l}27.2 \\
(1.8)\end{array}$ & $\begin{array}{l}10.7^{*} \\
(2.7)\end{array}$ & $\begin{array}{l}11.2 * \\
(2.5)\end{array}$ \\
\hline Quarter 4 & $\begin{array}{l}+4.4 \\
(2.2)\end{array}$ & $\begin{array}{l}27.4 \\
(1.8)\end{array}$ & $\begin{array}{l}17.0^{*} \\
(2.8)\end{array}$ & $\begin{array}{l}17.2^{*} \\
(2.6)\end{array}$ \\
\hline Quarter 5 & $\begin{array}{l}50.4 \\
(2.2)\end{array}$ & $\begin{array}{l}30.4 \\
(1.9)\end{array}$ & $\begin{array}{l}20.0^{*} \\
(3.0)\end{array}$ & $\begin{array}{l}20.0^{*} \\
(2.8)\end{array}$ \\
\hline Quarter 6 & $\begin{array}{l}+7.9 \\
(2.3)\end{array}$ & $\begin{array}{l}32.5 \\
(1.9)\end{array}$ & $\begin{array}{l}15.4^{*} \\
(3.0)\end{array}$ & $\begin{array}{l}15.5 * \\
(2.8)\end{array}$ \\
\hline \multicolumn{5}{|c|}{$\begin{array}{l}\text { D. Percentage who worked full time } \\
\text { (130 or more hours per month) }\end{array}$} \\
\hline Quarter -1 & $\begin{array}{r}+.5 \\
(0.6)\end{array}$ & $\begin{array}{r}5.4 \\
(0.7)\end{array}$ & $\begin{array}{r}-0.9 \\
(0.9)\end{array}$ & -- \\
\hline Quarter 1 & $\begin{array}{r}10.8 \\
(1.0)\end{array}$ & $\begin{array}{r}8.5 \\
(0.8)\end{array}$ & $\begin{array}{r}2.3 \\
(1.3)\end{array}$ & $(1.1)^{*}$ \\
\hline Quarter 2 & $\begin{array}{l}1+6 \\
(1.1)\end{array}$ & $\begin{array}{r}9.8 \\
(0.9)\end{array}$ & $\begin{array}{l}4.8^{*} \\
(1.4)\end{array}$ & $(1.3)^{*}$ \\
\hline Quarter 3 & $\begin{array}{r}18.2 \\
(1.2)\end{array}$ & $\begin{array}{r}11.0 \\
(1.0)\end{array}$ & $(1.5)$ & $\left(\begin{array}{l}7.5^{*} \\
(1.5)\end{array}\right.$ \\
\hline Quarter 4 & $\begin{array}{l}22.1 \\
(1.3)\end{array}$ & $\begin{array}{l}11.0 \\
(1.0)\end{array}$ & $\begin{array}{l}11.1^{*} \\
(1.6)\end{array}$ & $\begin{array}{l}11.2^{*} \\
(1.5)\end{array}$ \\
\hline Quarter 5 & $\begin{array}{r}25.3 \\
(1.3)\end{array}$ & $\begin{array}{r}12.3 \\
(1.0)\end{array}$ & $\begin{array}{l}13.0^{*} \\
(1.7)\end{array}$ & $\begin{array}{l}12.9{ }^{*} \\
(1.6)\end{array}$ \\
\hline Quarter 6 & $\begin{array}{r}23.9 \\
(1.4)\end{array}$ & $\begin{array}{l}13.0 \\
(1.0)\end{array}$ & $\begin{array}{l}10.9^{*} \\
(1.7)\end{array}$ & $\begin{array}{l}11.0^{*} \\
(1.7)^{*}\end{array}$ \\
\hline
\end{tabular}


Table 3 (continued)

\begin{tabular}{|c|c|c|c|c|}
\hline $\begin{array}{l}\text { Outcome Measure } \\
\text { and Time Period }\end{array}$ & $\begin{array}{r}\text { Program } \\
\text { Group } \\
\end{array}$ & $\begin{array}{r}\text { Control } \\
\text { Group } \\
\end{array}$ & $\begin{array}{r}\text { Unadjusted } \\
\text { Impact } \\
\end{array}$ & $\begin{array}{r}\text { Adjusted } \\
\text { Impact } \\
\end{array}$ \\
\hline \multicolumn{5}{|c|}{$\begin{array}{l}\text { E. Average percentage who worked part time } \\
\text { each month (less than } 130 \text { hours/month) }\end{array}$} \\
\hline Quarter -1 & $\begin{array}{l}15.3 \\
(1.1)\end{array}$ & $\begin{array}{r}12.6 \\
(1.0)\end{array}$ & $\begin{array}{r}2.6 \\
(1.5)\end{array}$ & -- \\
\hline Quarter l & $\begin{array}{l}13.1 \\
(1.0)\end{array}$ & $\begin{array}{l}13.9 \\
(1.0)\end{array}$ & $\begin{array}{r}-0.7 \\
(1.4)\end{array}$ & $\begin{array}{r}-2.2 \\
(1.2)\end{array}$ \\
\hline Quarter 2 & $\begin{array}{l}12.5 \\
(1.0)\end{array}$ & $\begin{array}{l}14.4 \\
(1.0)\end{array}$ & $\begin{array}{r}-1.8 \\
(1.4)\end{array}$ & $\begin{array}{l}-3.1^{*} \\
(1.3)\end{array}$ \\
\hline Quarter 3 & $\begin{array}{l}13.9 \\
(1.0)\end{array}$ & $\begin{array}{l}14.3 \\
(1.1)\end{array}$ & $\begin{array}{r}-0.3 \\
(1.5)\end{array}$ & $\begin{array}{r}-1.4 \\
(1.4)\end{array}$ \\
\hline Quarter 4 & $\begin{array}{l}14.0 \\
(1.0)\end{array}$ & $\begin{array}{l}14.8 \\
(1.1)\end{array}$ & $\begin{array}{r}-0.8 \\
(1.5)\end{array}$ & $\begin{array}{l}-1.6 \\
(1.4)\end{array}$ \\
\hline Quarter 5 & $\begin{array}{l}15.5 \\
(1.0)\end{array}$ & $\begin{array}{l}15.4 \\
(1.1)\end{array}$ & $\begin{array}{r}0.2 \\
(1.5)\end{array}$ & $\begin{array}{r}-0.4 \\
(1.4)\end{array}$ \\
\hline Quarter 6 & $\begin{array}{l}15.4 \\
(1.1)\end{array}$ & $\begin{array}{l}17.7 \\
(1.1)\end{array}$ & $\begin{array}{r}-2.2 \\
(1.6)\end{array}$ & $\begin{array}{l}-3.0^{*} \\
(1.5)\end{array}$ \\
\hline \multicolumn{5}{|c|}{$\begin{array}{l}\text { F. Average percentage } \\
\text { receiving LA each month }\end{array}$} \\
\hline Quarter -1 & $\begin{array}{l}99.6 \\
(0.1)\end{array}$ & $\begin{array}{l}99.6 \\
(0.1)\end{array}$ & $\begin{array}{r}0.1 \\
(0.2)\end{array}$ & -- \\
\hline Quarter I & $\begin{array}{r}98.2 \\
(0.3)\end{array}$ & $\begin{array}{r}97.9 \\
(0.4)\end{array}$ & $\begin{array}{r}0.3 \\
(0.5)\end{array}$ & $\begin{array}{r}0.3 \\
(0.5)\end{array}$ \\
\hline Quarter 2 & $\begin{array}{r}90.0 \\
(0.9)\end{array}$ & $\begin{array}{l}93.8 \\
(0.7)\end{array}$ & $\begin{array}{l}-3.7^{*} \\
(1.1)\end{array}$ & $\begin{array}{l}-3.8 * \\
(1.1)\end{array}$ \\
\hline Quarter 3 & $\begin{array}{l}81.7 \\
(1.2)\end{array}$ & $\begin{array}{r}89.5 \\
(0.9)\end{array}$ & $\begin{array}{l}.7 .7^{*} \\
(1.5)\end{array}$ & $\begin{array}{l}-7.6^{*} \\
(1.5)\end{array}$ \\
\hline Quarter 4 & $\begin{array}{l}76.5 \\
(1.3)\end{array}$ & $\begin{array}{l}86.3 \\
(1.0)\end{array}$ & $\begin{array}{l}-9.8 * \\
(1.7)\end{array}$ & $\begin{array}{l}-9.7 * \\
(1.6)\end{array}$ \\
\hline Quarter 5 & $\begin{array}{r}71.3 \\
(1.4)\end{array}$ & $\begin{array}{r}84.8 \\
(1.1)\end{array}$ & $\begin{array}{l}-13.6^{*} \\
(1.8)\end{array}$ & $\begin{array}{l}-13.5 * \\
(1.7)\end{array}$ \\
\hline Quarter 6 & $\begin{array}{r}67.5 \\
(1.5)\end{array}$ & $\begin{array}{r}81.4 \\
(1.2)\end{array}$ & $\begin{array}{c}-13.8 * \\
(1.9)\end{array}$ & $\begin{array}{c}-13.8 \\
(1.9)\end{array}$ \\
\hline
\end{tabular}


Table 3 (continued)

\begin{tabular}{|c|c|c|c|c|}
\hline $\begin{array}{l}\text { Outcome Measure } \\
\text { and Time Period }\end{array}$ & $\begin{array}{r}\text { Program } \\
\text { Group } \\
\end{array}$ & $\begin{array}{r}\text { Control } \\
\text { Group } \\
\end{array}$ & $\begin{array}{r}\text { Unadjusted } \\
\text { Impact }\end{array}$ & $\begin{array}{r}\text { Adjusted } \\
\text { Impact } \\
\end{array}$ \\
\hline \multicolumn{5}{|c|}{ G. Average monthly LA payments } \\
\hline Quarter -1 & $\begin{array}{r}883.6 \\
(9.1)\end{array}$ & $\begin{array}{r}877.7 \\
(9.0)\end{array}$ & $\begin{array}{r}5.9 \\
(12.8)\end{array}$ & -- \\
\hline Quarter 1 & $\begin{array}{r}877.1 \\
(9.7)\end{array}$ & $\begin{array}{r}869.2 \\
(9.8)\end{array}$ & $\begin{array}{r}7.9 \\
(13.8)\end{array}$ & $\begin{array}{r}4.7 \\
(7.3)\end{array}$ \\
\hline Quarter 2 & $\begin{array}{r}817.0 \\
(11.9)\end{array}$ & $\begin{array}{r}840.3 \\
(11.1)\end{array}$ & $\begin{array}{r}-23.3 \\
(16.3)\end{array}$ & $\begin{array}{l}-27.7^{*} \\
(11.4)\end{array}$ \\
\hline Quarter 3 & $\begin{array}{r}743.2 \\
(13.8)\end{array}$ & $\begin{array}{l}810.6 \\
(12.3)\end{array}$ & $\begin{array}{l}-67.4 * \\
(18.5)\end{array}$ & $\begin{array}{l}-69.3 * \\
(14.6)\end{array}$ \\
\hline Quarter 4 & $\begin{array}{l}702.7 \\
(14.5)\end{array}$ & $\begin{array}{l}790.4 \\
(13.1)\end{array}$ & $\begin{array}{l}-87.7^{*} \\
(19.5)\end{array}$ & $\begin{array}{l}-88.6 * \\
(16.0)\end{array}$ \\
\hline Quarter 5 & $\begin{array}{r}655.7 \\
(15.0)\end{array}$ & $\begin{array}{r}772.3 \\
(13.7)\end{array}$ & $\begin{array}{l}-116.6 * \\
(20.3)\end{array}$ & $\begin{array}{l}-117.5^{*} \\
(17.1)\end{array}$ \\
\hline Quarter 6 & $\begin{array}{r}618.9 \\
(15.8)\end{array}$ & $\begin{array}{r}753.2 \\
(14.3)\end{array}$ & $\begin{array}{l}-134.3^{*} \\
(21.4)\end{array}$ & $\begin{array}{l}-134.8^{*} \\
(18.7)\end{array}$ \\
\hline \multicolumn{5}{|c|}{$\begin{array}{l}\text { H. Percentage receiving IA or } \\
\text { SSP supplement payments }\end{array}$} \\
\hline Quarter -1 & $\begin{array}{l}99.6 \\
(0.1)\end{array}$ & $\begin{array}{l}99.6 \\
(0.1)\end{array}$ & $\begin{array}{r}0.1 \\
(0.2)\end{array}$ & -- \\
\hline Quarter I & $\begin{array}{r}100.0 \\
(0.4)\end{array}$ & $\begin{array}{l}97.9 \\
(0.4)\end{array}$ & $\begin{array}{l}2.1^{*} \\
(0.5)\end{array}$ & $\begin{array}{l}2.0 * \\
(0.5)\end{array}$ \\
\hline Quarter 2 & $\begin{array}{l}99.7 \\
(0.6)\end{array}$ & $\begin{array}{l}93.8 \\
(0.7)\end{array}$ & $\begin{array}{l}5.9 * \\
(0.9)\end{array}$ & $\begin{array}{l}5.7 * \\
(0.9)\end{array}$ \\
\hline Quarter 3 & $\begin{array}{l}96.6 \\
(0.8)\end{array}$ & $\begin{array}{l}89.5 \\
(0.9)\end{array}$ & $\begin{array}{c}7.1{ }^{*} \\
(1.2)\end{array}$ & $\begin{array}{c}7.0^{*} \\
(1.2)\end{array}$ \\
\hline Quarter 4 & $\begin{array}{l}95.0 \\
(0.9)\end{array}$ & $\begin{array}{l}86.3 \\
(1.0)\end{array}$ & $\begin{array}{c}8.8 * \\
(1.4)\end{array}$ & $\begin{array}{c}8.6^{*} \\
(1.4)\end{array}$ \\
\hline Quarter 5 & $\begin{array}{l}94.1 \\
(1.0)\end{array}$ & $\begin{array}{l}84.8 \\
(1.1)\end{array}$ & $\begin{array}{l}9.2 * \\
(1.5)\end{array}$ & $\begin{array}{l}8.9^{*} \\
(1.5)\end{array}$ \\
\hline Quarter 6 & $\begin{array}{l}91.4 \\
(1.0)\end{array}$ & $\begin{array}{l}81.4 \\
(1.2)\end{array}$ & $\begin{array}{l}10.0 * \\
(1.6)\end{array}$ & $\begin{array}{c}9.8^{*} \\
(1.6)\end{array}$ \\
\hline
\end{tabular}


Table 3 (continued)

\begin{tabular}{lcccc}
\hline $\begin{array}{l}\text { Outcome Measure } \\
\text { and Time Period }\end{array}$ & $\begin{array}{c}\text { Program } \\
\text { Group }\end{array}$ & $\begin{array}{c}\text { Control } \\
\text { Group }\end{array}$ & $\begin{array}{c}\text { Unadjusted } \\
\text { Impact }\end{array}$ & $\begin{array}{c}\text { Adjusted } \\
\text { Impact }\end{array}$ \\
\hline $\begin{array}{l}\text { I. Average monthly LA and } \\
\text { SSP supplement payments (\$) }\end{array}$ & & & & \\
\hline Quarter -1 & 883.6 & 877.7 & 5.9 & - \\
& $(9.1)$ & $(9.0)$ & $(12.8)$ & \\
Quarter 1 & 891.2 & 869.2 & 22.0 & $18.6^{*}$ \\
& $(9.5)$ & $(9.8)$ & $(13.7)$ & $(7.3)$ \\
Quarter 2 & 899.7 & 840.3 & $59.5 *$ & $54.4^{*}$ \\
& $(10.3)$ & $(11.1)$ & $(15.1)$ & $(10.5)$ \\
Quarter 3 & 870.4 & 810.6 & $59.8 *$ & $56.6 *$ \\
& $(11.4)$ & $(12.3)$ & $(16.8)$ & $(13.0)$ \\
Quarter 4 & 858.7 & 790.4 & $68.3 *$ & $66.0 *$ \\
& $(11.7)$ & $(13.1)$ & $(17.5)$ & $(14.0)$ \\
Quarter 5 & 865.8 & 772.3 & $93.5 *$ & $89.6 *$ \\
& $(12.6)$ & $(13.7)$ & $(18.5)$ & $(15.3)$ \\
Quarter 6 & 839.5 & 753.2 & $86.3 *$ & $84.5^{*}$ \\
& $(12.8)$ & $(14.3)$ & $(19.2)$ & $(16.7)$ \\
\hline Sample size & 942 & 968 & & \\
\hline
\end{tabular}

SOURCE: SRDC's 18-month survey of the first cohort of SSP sample members.

NOTE: Standard errors are in parentheses.

An asterisk indicates that the impact estimate is statistically significant at the 5 percent level.

The unadjusted impact is the simple difference in mean outcomes between the program

and control groups. The adjusted impact is a regression-adjusted difference, controlling for the lagged (quarter -1 ) value of the dependent variable; age; province; number of children in three age ranges; number of adults in the household; a dummy if the person ever worked for pay; the number of years of paid work before baseline; dummies for two levels of schooling (high school graduation with no post-secondary education and some post-secondary education); dummies for the presence of self-reported physical or emotional problems at baseline: a dummy for subsidized housing at baseline; dummies for First Nation, European or Canadian, or Asian ancestry; a dummy for being born outside of Canada; and a measure of the number of months on IA in the three years before baseline. 
Table 4

Relative Generosity of SSP by Province and Family Size for the 18-Month Survey Sample

\begin{tabular}{llrrrrr} 
& & \multicolumn{2}{c}{ British Columbia } & & \multicolumn{2}{c}{ New Brunswick } \\
Measure & 1 Child & $\begin{array}{r}2 \text { or More } \\
\text { Children }\end{array}$ & & 1 Child & $\begin{array}{r}\text { 2 or More } \\
\text { Children }\end{array}$ \\
\hline 1. Predicted hourly wage (\$) & 7.49 & 7.38 & 5.61 & 5.48 \\
2. Predictions within \$1.00 of minimum wage (\%) & 40.4 & 45.6 & 75.5 & 80.6 \\
3. Working at baseline (\%) & 16.6 & 17.4 & 24.9 & 18.4
\end{tabular}

\section{Generosity, ignoring tares and other transfers"}

4. Average statutory IA amount at 0 hours of work per month ${ }^{\mathrm{b}}(\$)$

5. Earnings plus supplement under SSP at 130 hours of work per month (\$)

6. Additional income: SSP at 130 hours minus statutory IA (\$)

\begin{tabular}{|c|c|c|}
\hline 1,046 & 790 & 902 \\
\hline 1.07 & 0.64 & 1.27 \\
\hline
\end{tabular}

7. Additional income/1A (row 6/row 4) (\$)

\section{Generosity, including taxes and other transfers ${ }^{c}$}

8. Average disposable income under IA at 130 hours of work per month (\$)

9. Average disposable income under SSP at 130 hours of work per month (\$)

10. Additional income: SSP at 130 hours of work per month minus IA (\$)

11. Additional income/IA (row 10/row 8) (\$)

SOURCE: SRDC's 18-month survey of the first cohort of SSP sample members.

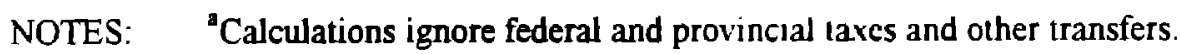

${ }^{b}$ Average monthly IA payment at 0 hours of work is based on family size, and ignores any allowances or reductions.

${ }^{c}$ Calculations are based on disposable income. assuming that the individual works 130 hours per month, and account for federal and provincial taves and tax credits, child support payments, payroll taxes, and applicable child care subsidies. Averages are based on program group subsamples only. 
Table 5

Average Monthly SSP Program Impacts by Province and Family Size for the SSP 18-Month Survey Sample

Measure and
Follow-Up Period
Average monthly hours of work

Quarter 1

$\begin{array}{rrrr}-7.5 & 8.2 * & 11.6 * & -1.2 \\ (4.2) & (3.9) & (5.8) & (5.7)\end{array}$

Quarter 2

$12.8 *$

$14.1 *$

$+.3$

$(+6)$

(4.1)

(6.3)

(6.6)

Quarter 3

0.2

$17.3 *$

$14.5 *$

$14.1 *$

(4.9)

(4.4)

(6.3)

(6.9)

Quarter 4

\section{2}

20.9

21.0 *

22.0 *

(5.0)

(4.7)

(6.9)

(6.9)

Quarter 5

$14.5 *$

28.7 *

15.6 *

$17.9 *$

(5.4)

(4.9)

(7.1)

(7.2)

Quarter 6

$$
5.0
$$

$28.8 *$

13.8

9.6

(54)

(4.8)

(7.4)

(7.3)

\section{Average monthly earnings (S)}

Quarter 1

$$
-63.0
$$

(37.8)

Quarter 2

$$
45 .
$$

$(+3+)$

$76.2 *$

86.7

$-21.8$

(38.8)

(38.8)

(33.4)

Quarter 3

$$
\begin{array}{r}
-7.7 \\
(+6.7)
\end{array}
$$

$104.3 *$

$95.6 *$

11.8

$$
\text { (40.6) }
$$

(42.4)

$132.3 *$

$99.3 *$

63.8

(43.1)

(43.0)

Quarter 4

$$
\begin{array}{r}
57.0 \\
(+7.2)
\end{array}
$$

$156.9 *$

(45.2)

160.8 *

(44.3)

$1174 *$

(41.9)

Quarter 5

$$
\begin{array}{r}
98.2 \\
(50.9)
\end{array}
$$

215.2
$(46.3)$

$119.4 *$

72.3

(45.3)

(46.8)

Quarter 6

227.1
$(45.6)$

85.9

(49.7)

(53.5)

(48.2) 
Table 5 (continued)

\begin{tabular}{|c|c|c|c|c|}
\hline \multirow[b]{2}{*}{$\begin{array}{l}\text { Measure and } \\
\text { Follow-Up Period }\end{array}$} & \multicolumn{2}{|c|}{ British Columbia } & \multicolumn{2}{|c|}{ New Brunswick } \\
\hline & 1 Child & $\begin{array}{r}2 \text { or More } \\
\text { Children } \\
\end{array}$ & 1 Child & $\begin{array}{c}2 \text { or More } \\
\text { Children } \\
\end{array}$ \\
\hline \multicolumn{5}{|c|}{ Averape monthly employment rate (\%) } \\
\hline Quarter I & $\begin{array}{r}-4.8 \\
(3.3)\end{array}$ & $\begin{array}{r}7.6 \\
(3.1)\end{array}$ & $\begin{array}{l}5.7 \\
4.8\end{array}$ & $\begin{array}{r}-3.2 \\
(4.4)\end{array}$ \\
\hline Quarter 2 & $\begin{array}{r}-4.7 \\
(3.4)\end{array}$ & $\begin{array}{r}10.5 \\
(3.2)\end{array}$ & $\begin{array}{r}5.9 \\
(4.9)\end{array}$ & $\begin{array}{r}-0.5 \\
(4.7)\end{array}$ \\
\hline Quarter 3 & $\begin{array}{r}0.0 \\
(3.6)\end{array}$ & $\begin{array}{r}13.8 \\
(3.3)\end{array}$ & $\begin{array}{r}6.3 \\
(4.9)\end{array}$ & $\begin{array}{r}6.8 \\
(4.9)\end{array}$ \\
\hline Quarter 4 & $\begin{array}{r}4.2 \\
(3.6)\end{array}$ & $\begin{array}{r}14.2 \\
(3.4)\end{array}$ & $\begin{array}{l}11.5 * \\
(5.0)\end{array}$ & $\begin{array}{l}13.3 * \\
(4.8)\end{array}$ \\
\hline Quarter 5 & $\begin{array}{c}9.3^{*} \\
(3.7)\end{array}$ & $\begin{array}{r}19.7 \\
(3.5)\end{array}$ & $\begin{array}{c}10.7 \\
(5.1)\end{array}$ & $\begin{array}{c}9.8 * \\
(5.0)\end{array}$ \\
\hline Quarter 6 & $\begin{array}{r}2.5 \\
(3.7)\end{array}$ & $\begin{array}{r}18.0 \\
(3.5)\end{array}$ & $\begin{array}{r}5.9 \\
(5.2)\end{array}$ & $\begin{array}{r}4.7 \\
(5.1)\end{array}$ \\
\hline
\end{tabular}

SOURCE: SRDC's 18-month survey of the first cohort of SSP sample members.

NOTE: Standard errors are in parentheses.

An asterisk indicates that the impact estimate is statistically significant at the 5 percent level Impacts are unadjusted differences in quarterly averages of monthly outcomes between program group and control group members in each subsample. 
Table 6

Analysis of Wage Distribution of Jobs Attributable to SSP, Both Provinces

\begin{tabular}{lrrrrr}
\hline & \multicolumn{2}{c}{ Percentage in Interval } & Percentage & Excess Share \\
\cline { 2 - 3 } & Program & Control & of Net Jobs & $\begin{array}{r}\text { of Net Jobs } \\
\text { Wage Interval }\end{array}$ \\
and Time Period & Group & Group & in Interval ${ }^{\mathbf{b}}$ & in Interval (\%) \\
\hline
\end{tabular}

\section{Month 13}

1. Not working

Working with wage

2. Missing wage ${ }^{d}$

3. Less than minimum wage ${ }^{e}$

4. Minimum to minimum $+\$ .99$

5. Minimum $+\$ 1.00-\$ 1.99$ above minimum

6. Minimum $+\$ 2.00-\$ 2.99$ above minimum

7. Minimum $+\$ 3.00$ or more above minimum
$58.8 \quad(1.6) \quad 72.4(1.4)$

$\begin{array}{rrrrrrrr}1.0 & (0.3) & 1.9 & (0.4) & -6.6 & (4.3) & -13.4 & (5.7) \\ 3.8 & (0.6) & 3.6 & (0.6) & 1.5 & (6.3) & -11.6 & (8.2) \\ 13.9 & (1.1) & 5.8 & (0.8) & 59.7 & (10.2) & 38.7 & (11.1) \\ 8.0 & (0.9) & 3.8 & (0.6) & 30.4 & (7.7) & 16.6 & (8.9) \\ 4.4 & (0.7) & 2.6 & (0.5) & 13.0 & (6.0) & 3.6 & (7.2) \\ 10.3 & (1.0) & 10.0 & (1.0) & 2.0 & (10.0) & -34.3 & (13.6)\end{array}$

\section{Month 17}

1. Not working

$61.3 \quad(1.6) \quad 68.8(1.5)$

\section{Working with wage}

2. Missing wage ${ }^{d}$

3. Less than minimum wage $e^{e}$

4. Minimum to minimum $+\$ .99$

5. Minimum $+\$ 1.00-\$ 1.99$ above minimum

6. Minimum $+\$ 2.00-\$ 2.99$ above minimum

7. Minimum $+\$ 3.00$ or more above minimum

$\begin{array}{rrrrrrrr}1.4 & (0.4) & 2.2 & (0.5) & -10.5 & (9.1) & -17.4 & (10.3) \\ 4.0 & (0.6) & 3.8 & (0.6) & 2.8(11.6) & -9.4 & (13.2) \\ 12.2 & (1.1) & 6.1 & (0.8) & 81.0(22.4) & 61.4 & (22.5) \\ 6.6 & (0.8) & 4.5 & (0.7) & 27.0 & (13.5) & 12.4 & (14.7) \\ 4.9 & (0.7) & 3.1 & (0.6) & 23.6(12.0) & 13.7 & (12.9) \\ 10.0 & (1.0) & 11.6 & (1.0) & -21.1 & (22.3) & -58.2 & (25.8)\end{array}$

NOTES: Standard errors are in parentheses.

"Percentage of all individuals (workers and non-workers) in the specified wage interval.

bercentage of net jobs attributable to SSP in the specified wage interval, in decimal terms (column 1 minus column 2)/(column2 minus column 1 of row 1 ).

'Difference between the percentage of net jobs attributable to SSP in the specified wage interval, and the percentage of control group workers' jobs in the wage interval, in decimal terms (column 3 minus (column 2/[column 1 minus column 2 of row 1]).

'Information on wages was missing for some individuals who may have been working in casual or piece-rate jobs with compensation that cannot be easily converted to an hourly wage.

'During the period under study, the minimum wage was $\$ 6.00$ per hour in British Columbia and $\$ 5.00$ per hour in New Brunswick. 
Table 7

Response Rates for the SSP 18-Month Survey Sample

\begin{tabular}{lrrrr}
\hline Sample & $\begin{array}{r}\text { Total } \\
\text { Sample } \\
(\%)\end{array}$ & $\begin{array}{r}\text { Program } \\
\text { Group } \\
\text { Only }(\%)\end{array}$ & $\begin{array}{r}\text { Control } \\
\text { Group } \\
\text { Only }(\%)\end{array}$ & $\begin{array}{r}\text { Control Group } \\
\text { Group }(\%)\end{array}$ \\
\hline Total sample (first cohort of the & 90.0 & 88.4 & 91.7 & $3.3^{*}$ \\
SSP research sample) & $(0.7)$ & $(1.0)$ & $(0.9)$ & $(1.3)$ \\
British Columbia & 89.0 & 87.3 & 90.7 & $3.4^{*}$ \\
& $(0.9)$ & $(1.3)$ & $(1.1)$ & $(1.7)$ \\
New Brunswick & 92.2 & 90.6 & 93.7 & 3.1 \\
& $(1.0)$ & $(1.6)$ & $(1.3)$ & $(2.0)$ \\
On IA, month 18 & 91.1 & 88.5 & 93.3 & $4.8 *$ \\
& $(0.7)$ & $(1.2)$ & $(0.9)$ & $(1.5)$ \\
Off IA, month 18 & 87.1 & 88.2 & 85.5 & -2.7 \\
& $(1.4)$ & $(1.7)$ & $(2.4)$ & $(2.9)$ \\
Difference: on IA vs. off IA $^{\mathrm{a}}$ & & & & $7.5 *$ \\
& $(1.0$ & 0.3 & 7.8 & $(3.3)$ \\
\hline
\end{tabular}

SOURCE: SRDC's 18-month survey of the first cohort of SSP sample members.

NOTES: Standard errors are in parentheses.

An asterisk indicates that the control group-program group difference is statistically significant at the 5 percent level.

${ }^{a}$ The difference in response rates between individuals who were receiving IA payments in month 18 and those who were not. The entry in column 4 represents the relative differential in response rates for individuals on and off IA in the control group and in the program group. 


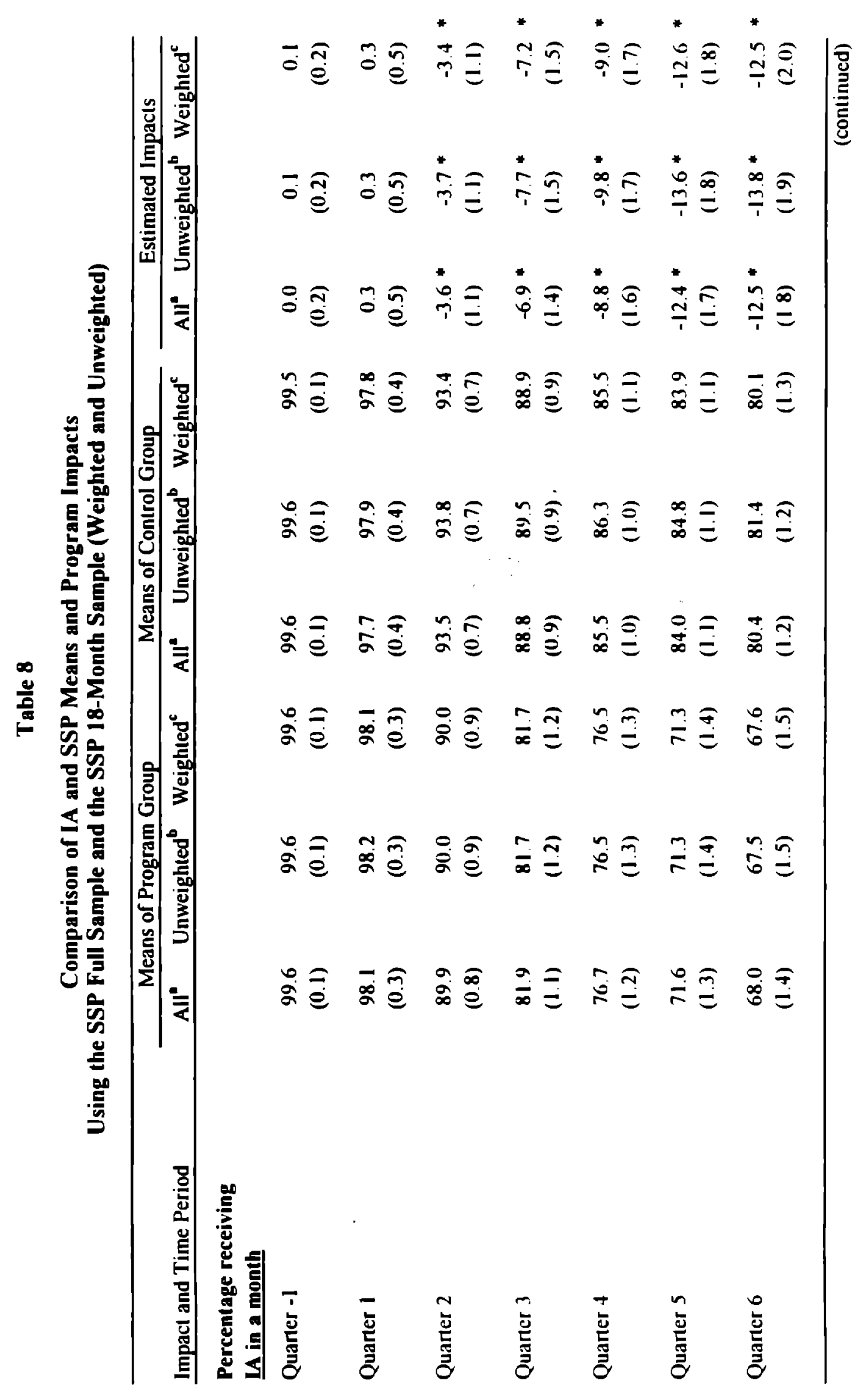




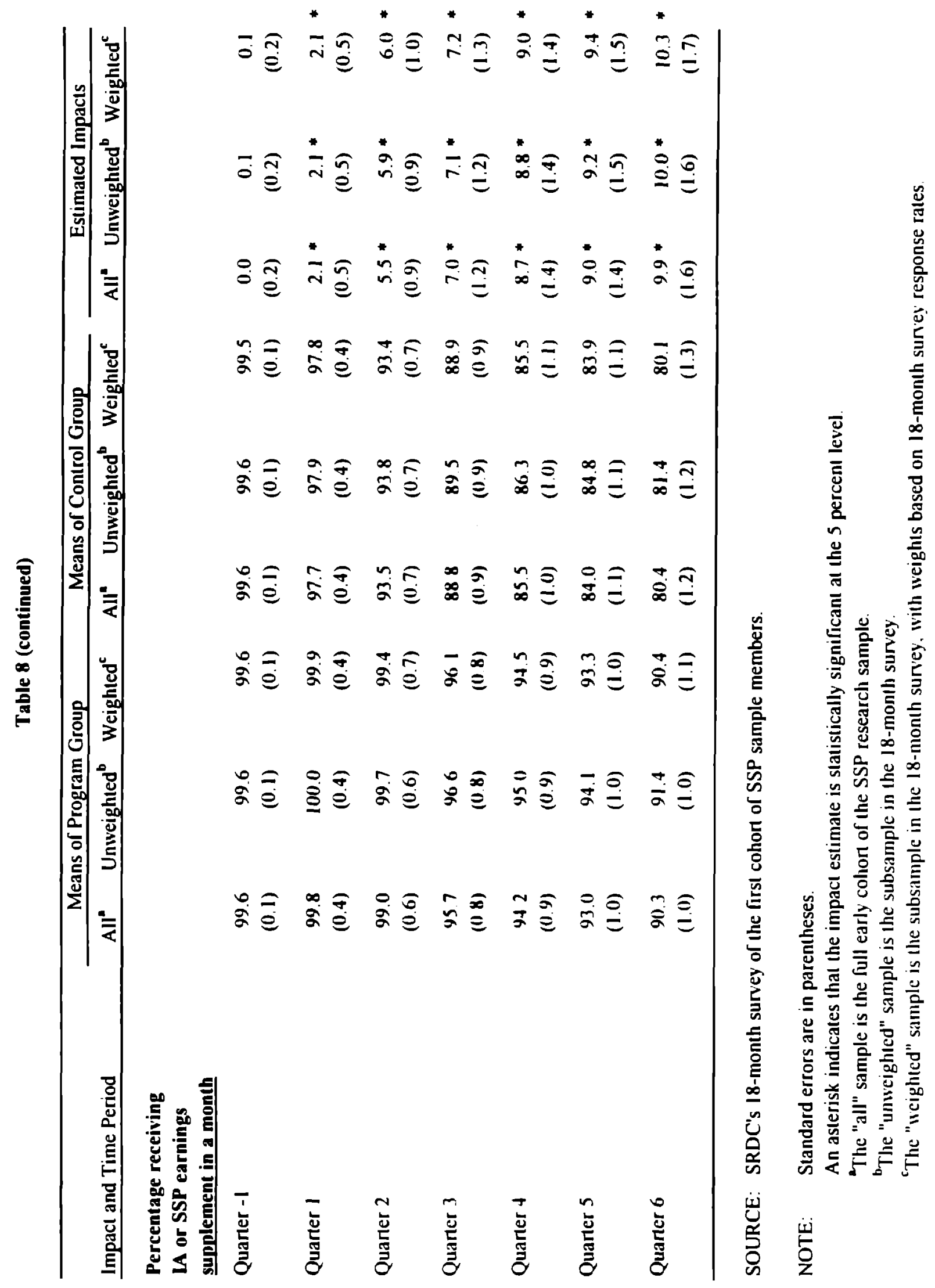


Table 9

Comparison of Mean Labour Market Outcomes and Program Impacts:

Unweighted and Weighted SSP 18-Month Survey Sample Respondents

\begin{tabular}{|c|c|c|c|c|c|c|}
\hline \multirow{3}{*}{$\begin{array}{l}\text { Outcome Measure } \\
\text { and Time Period }\end{array}$} & \multicolumn{2}{|c|}{ Unweighted Means } & \multicolumn{2}{|c|}{ Weighted Means } & \multirow{2}{*}{\multicolumn{2}{|c|}{ Estimated Impact }} \\
\hline & \multirow{2}{*}{$\begin{array}{c}\text { Program } \\
\text { Group }\end{array}$} & \multirow{2}{*}{$\begin{array}{l}\text { Control } \\
\text { Group }\end{array}$} & \multirow{2}{*}{$\begin{array}{l}\text { Program } \\
\text { Group }\end{array}$} & \multirow{2}{*}{$\begin{array}{l}\text { Control } \\
\text { Group }\end{array}$} & & \\
\hline & & & & & Unweighted & Weighted \\
\hline \multicolumn{7}{|c|}{$\begin{array}{l}\text { Average percentage } \\
\text { who work in a month }\end{array}$} \\
\hline Quarter -1 & $\begin{array}{r}19.8 \\
(1.2)\end{array}$ & $\begin{array}{r}18.0 \\
(1.2)\end{array}$ & $\begin{array}{l}19.7 \\
(1.2)\end{array}$ & $\begin{array}{r}18.3 \\
(1.2)\end{array}$ & $\begin{array}{r}1.8 \\
(1.7)\end{array}$ & $\begin{array}{r}1.4 \\
(1.7)\end{array}$ \\
\hline Quarter 1 & $\begin{array}{r}23.9 \\
\text { (1.3) }\end{array}$ & $\begin{array}{r}22.3 \\
\text { (1.3) }\end{array}$ & $\begin{array}{l}23.7 \\
(1.3)\end{array}$ & $\begin{array}{l}22.7 \\
(1.3)\end{array}$ & $\begin{array}{r}1.5 \\
(1.9)\end{array}$ & $\begin{array}{r}1.0 \\
(1.9)\end{array}$ \\
\hline Quarter 2 & $\begin{array}{l}27.1 \\
(1.4)\end{array}$ & $\begin{array}{r}24.2 \\
(1.3)\end{array}$ & $\begin{array}{l}26.8 \\
(1.4)\end{array}$ & $\begin{array}{r}24.7 \\
(1.3)\end{array}$ & $\begin{array}{r}2.9 \\
(1.9)\end{array}$ & $\begin{array}{r}2.1 \\
(1.9)\end{array}$ \\
\hline Quarter 3 & $\begin{array}{r}32.2 \\
(1.5)\end{array}$ & $\begin{array}{l}25.3 \\
(1.4)\end{array}$ & $\begin{array}{l}31.8 \\
(1.5)\end{array}$ & $\begin{array}{r}25.8 \\
(1.4)\end{array}$ & $\begin{array}{c}6.9 * \\
(2.0)\end{array}$ & $\begin{array}{l}6.0^{*} \\
(2.0)\end{array}$ \\
\hline Quarter 4 & $\begin{array}{r}36.1 \\
(1.5)\end{array}$ & $\begin{array}{r}25.8 \\
(1.4)\end{array}$ & $\begin{array}{r}35.7 \\
(1.5)\end{array}$ & $\begin{array}{r}26.2 \\
(1.4)\end{array}$ & $\begin{array}{l}10.3^{*} \\
(2.0)\end{array}$ & $\begin{array}{l}9.4 * \\
(2.0)\end{array}$ \\
\hline Quarter 5 & $\begin{array}{l}40.8 \\
(1.5)\end{array}$ & $\begin{array}{l}27.7 \\
(1.4)\end{array}$ & $\begin{array}{l}40.1 \\
(1.5)\end{array}$ & $\begin{array}{l}28.2 \\
(1.4)\end{array}$ & $\begin{array}{l}13.1 * \\
(2.1)\end{array}$ & $\begin{array}{l}12.0 * \\
(2.1)\end{array}$ \\
\hline Quarter 6 & $\begin{array}{r}39.3 \\
(1.5)\end{array}$ & $\begin{array}{r}30.6 \\
(1.4)\end{array}$ & $\begin{array}{r}38.6 \\
(1.5)\end{array}$ & $\begin{array}{l}31.2 \\
(1.4)\end{array}$ & $\begin{array}{l}8.7^{*} \\
(2.1)\end{array}$ & $\begin{array}{l}7+* \\
(2.1)\end{array}$ \\
\hline \multicolumn{7}{|c|}{ Average monthly earnings } \\
\hline Quarter -1 & $\begin{array}{r}102.7 \\
(8.3)\end{array}$ & $\begin{array}{r}110.0 \\
(9.7)\end{array}$ & $\begin{array}{r}101.9 \\
(8.3)\end{array}$ & $\begin{array}{r}111.8 \\
(9.8)\end{array}$ & $\begin{array}{r}-7.3 \\
(12.8)\end{array}$ & $\begin{array}{r}-9.9 \\
(12.8)\end{array}$ \\
\hline Quarter 1 & $\begin{array}{r}186.3 \\
(14.3)\end{array}$ & $\begin{array}{r}169.2 \\
(14.0)\end{array}$ & $\begin{array}{r}184.1 \\
(14.2)\end{array}$ & $\begin{array}{r}173.7 \\
(14.2)\end{array}$ & $\begin{array}{r}17.1 \\
(20.0)\end{array}$ & $\begin{array}{r}10.3 \\
(20.1)\end{array}$ \\
\hline Quarter 2 & $\begin{array}{r}233.7 \\
(15.7)\end{array}$ & $\begin{array}{r}194.5 \\
(15.5)\end{array}$ & $\begin{array}{r}229.8 \\
(15.5)\end{array}$ & $\begin{array}{l}201.0 \\
(15.8)\end{array}$ & $\begin{array}{r}39.2 \\
(22.1)\end{array}$ & $\begin{array}{r}287 \\
(22.1)\end{array}$ \\
\hline Quarter 3 & $\begin{array}{r}284.0 \\
(16.9)\end{array}$ & $\begin{array}{l}214.1 \\
(16.5)\end{array}$ & $\begin{array}{r}278.7 \\
(16.8)\end{array}$ & $\begin{array}{r}221.4 \\
(16.8)\end{array}$ & $\begin{array}{l}69.9 * \\
(23.6)\end{array}$ & $\begin{array}{c}57.3 \\
(23.7)\end{array}$ \\
\hline Quarter 4 & $\begin{array}{r}329.5 \\
(17.9)\end{array}$ & $\begin{array}{r}210.8 \\
(16.1)\end{array}$ & $\begin{array}{r}323.5 \\
(17.8)\end{array}$ & $\begin{array}{l}217.7 \\
(16.4)\end{array}$ & $\begin{array}{l}118.7^{*} \\
(24.1)\end{array}$ & $\begin{array}{l}105.9 * \\
(2+2)\end{array}$ \\
\hline Quarter 5 & $\begin{array}{r}372.6 \\
(18.8)\end{array}$ & $\begin{array}{r}235.5 \\
(17.0)\end{array}$ & $\begin{array}{r}363.6 \\
(18.6)\end{array}$ & $\begin{array}{r}243.3 \\
(17.3)\end{array}$ & $\begin{array}{l}137.0^{*} \\
(25.4)\end{array}$ & $\begin{array}{l}120.3 \\
(25.4)\end{array}$ \\
\hline Quarter 6 & $\begin{array}{r}359.0 \\
(19.5)\end{array}$ & $\begin{array}{r}254.6 \\
(17.4)\end{array}$ & $\begin{array}{r}348.7 \\
(19.3)\end{array}$ & $\begin{array}{r}263.6 \\
(17.8)\end{array}$ & $\begin{array}{l}104.4^{*} \\
(26.1)\end{array}$ & $\begin{array}{c}85.1 \\
(26.2)\end{array}$ \\
\hline
\end{tabular}

SOURCE: SRDC's 18-month survey of the first cohort of SSP sample members.

NOTES: Standard errors are in parentheses.

An asterisk indicates that the impact estimate is statistically significant at the 5 percent level. 